\title{
Lysosomal enzyme cathepsin D protects against alpha-synuclein aggregation and toxicity
} Liyan Qiao ${ }^{1}$, Shusei Hamamichi², Kim A Caldwell2,3,4,5, Guy A Caldwell2,3,4,5, Talene A Yacoubian ${ }^{3,4,5}$, Scott Wilson ${ }^{3}$, Zuo-Lei Xie ${ }^{1}$, Lisa D Speake, Rachael Parks ${ }^{1}$, Donna Crabtree ${ }^{1}$, Qiuli Liang ${ }^{1}$, Stephen Crimmins ${ }^{1}$, Lonnie Schneider ${ }^{1}$, Yasuo Uchiyama ${ }^{6}$, Takeshi Iwatsubo ${ }^{7}$, Yi Zhou ${ }^{3}$, Lisheng Peng 8 , YouMing Lu ${ }^{8}$, David G Standaert ${ }^{3,4}$, Ken C Walls ${ }^{1}$, John J Shacka1,5,9, Kevin A Roth ${ }^{1,3,5}$ and Jianhua Zhang*1,3,5

Address: ${ }^{1}$ Department of Pathology, University of Alabama at Birmingham, Birmingham, USA, ${ }^{2}$ Department of Biological Sciences, The University of Alabama, Tuscaloosa, USA, ${ }^{3}$ Department of Neurobiology, University of Alabama at Birmingham, Birmingham, USA, ${ }^{4}$ Department of Neurology, University of Alabama at Birmingham, Birmingham, USA, ${ }^{5}$ Center for Neurodegeneration and Experimental Therapeutics, University of Alabama at Birmingham, Birmingham, USA, ${ }^{6}$ Department of Cell Biology and Neurosciences, Osaka University, Osaka, Japan, ${ }^{7}$ Department of Neuropathology, Graduate School of Medicine, Department of Neuropathology and Neuroscience, Graduate School of Pharmaceutical Sciences, University of Tokyo, Tokyo, Japan, ${ }^{8}$ Biomolecular Science Center, Burnett College of Biomedical Sciences, Orlando, USA and ${ }^{9}$ Department of Veterans Affairs, Birmingham VA Medical Center, Birmingham, AL35294, USA

Email: Liyan Qiao - lqiao@uab.edu; Shusei Hamamichi - hamam@bama.ua.edu; Kim A Caldwell - kcaldwell@ua.edu; Guy A Caldwell - gcaldwell@ua.edu; Talene A Yacoubian - tyacoub@uab.edu; Scott Wilson - wilson@nrc.uab.edu; ZuoLeiXie - xie_zl1969@yahoo.com.cn; Lisa D Speake - ldspeake@bsu.edu; Rachael Parks -rparks1@mvnu.edu; Donna Crabtree - donna.crabtree@gmail.com; Qiuli Liang - lianglql02@gmail.com; Stephen Crimmins - scrimmins@nrc.uab.edu; Lonnie Schneider - lonnie11@uab.edu; Yasuo Uchiyama - y-uchi@anat1.med.osaka-u.ac.jp; Takeshi Iwatsubo - iwatsubo@mol.f.u-tokyo.ac.jp; Yi Zhou - yzhou@nrc.uab.edu; Lisheng Peng - youming@mail.ucf.edu; YouMing Lu - youming@mail.ucf.edu;

David G Standaert - dstandaert@uab.edu; Ken C Walls - kcwalls@uab.edu; John J Shacka - shacka@uab.edu; Kevin A Roth - karoth@uab.edu; Jianhua Zhang* - zhanja@uab.edu

* Corresponding author

\section{Published: 21 November 2008}

Molecular Brain 2008, I:17 doi:10.1186/1756-6606-I-17
Received: 18 September 2008

Accepted: 21 November 2008

This article is available from: http://www.molecularbrain.com/content///I/17

(C) 2008 Qiao et al; licensee BioMed Central Ltd.

This is an Open Access article distributed under the terms of the Creative Commons Attribution License (http://creativecommons.org/licenses/by/2.0), which permits unrestricted use, distribution, and reproduction in any medium, provided the original work is properly cited.

\begin{abstract}
$\alpha$-synuclein ( $\alpha$-syn) is a main component of Lewy bodies (LB) that occur in many neurodegenerative diseases, including Parkinson's disease (PD), dementia with LB (DLB) and multi-system atrophy. $\alpha$-syn mutations or amplifications are responsible for a subset of autosomal dominant familial PD cases, and overexpression causes neurodegeneration and motor disturbances in animals. To investigate mechanisms for $\alpha$-syn accumulation and toxicity, we studied a mouse model of lysosomal enzyme cathepsin D (CD) deficiency, and found extensive accumulation of endogenous $\alpha$-syn in neurons without overabundance of $\alpha$-syn mRNA. In addition to impaired macroautophagy, CD deficiency reduced proteasome activity, suggesting an essential role for lysosomal CD function in regulating multiple proteolytic pathways that are important for $\alpha$-syn metabolism. Conversely, CD overexpression reduces $\alpha$-syn aggregation and is neuroprotective against $\alpha$-syn overexpression-induced cell death in vitro. In a $C$. elegans model, CD deficiency exacerbates $\alpha$-syn accumulation while its overexpression is protective against $\alpha$-syn-induced dopaminergic neurodegeneration. Mutated CD with diminished enzymatic activity or overexpression of cathepsins $B(C B)$ or $L(C L)$ is not protective in the worm model, indicating a unique requirement for enzymatically active $C D$. Our data identify a conserved CD function in $\alpha$-syn degradation and identify CD as a novel target for LB disease therapeutics.
\end{abstract}




\section{Introduction}

Patients with $\alpha$-synuclein ( $\alpha$-syn) A53T, A30P, E46K mutations or gene amplification develop typical Parkinson's disease (PD) and often an associated dementia[1]. However, in $>90 \%$ of PD cases, and almost all dementia with Lewy body (DLB) and Lewy body variant of Alzheimer's disease (LBVAD) cases, $\alpha$-syn aggregation occurs yet without a clear evidence of mutation or up-regulation of $\alpha$-syn mRNA transcription. Therefore, impaired $\alpha$-syn clearance may play a more important role than $\alpha$-syn overexpression in neuronal $\alpha$-syn accumulation and neurodegenerative disease pathogenesis.

Experiments in vitro have shown that $\alpha$-syn can be cleared by the cytosolic ubiquitin-proteasome system (UPS), and/ or lysosome-mediated autophagic pathways[2]. The UPS degrades short-lived, misfolded and/or damaged proteins via an ubiquitin-dependent signaling pathway. Macroautophagy is initiated by de novo synthesis of double membrane vesicles in the cytoplasm. These vesicles encircle long-lived or damaged proteins or organelles by an unknown signaling mechanism and deliver these cargos to lysosomes for degradation. Chaperone-mediated autophagy (CMA) is initiated by chaperones binding to KFERQ-consensus sequence-containing cytosolic proteins followed by delivery to the lysosomes via lysosomal membrane LAMP-2a receptors. Wildtype $\alpha$-syn has a pentapeptide sequence that can serve as a CMA recognition motif and can be translocated to the lysosome, while dopamine modified or pathogenic A53T and A30P mutant $\alpha$-syn block CMA $[3,4]$.

Lysosomal function declines with age in the human brain[5]. Accumulation of autophagic vacuoles (AVs) has been reproducibly observed in postmortem $\mathrm{AD}$ and $\mathrm{PD}$ patient brains compared to normal controls, consistent with either an overproduction of AVs or a deficit in autophagolysosomal clearance[6]. Enhancing macroautophagy by either mTOR-dependent or independent mechanisms can help clear aggregation-prone proteins, including huntingtin, A53T and A30P mutant $\alpha$-syn $[7,8]$. However, because both macroautophagy and CMA are dependent on intact lysosomes, enhancing macroautophagy may not be effective in clearing potentially neurotoxic proteins if lysosomal function is impaired. Understanding the role of lysosomal enzymes in $\alpha$-syn clearance may provide new strategies for LBVAD, DLB, and PD therapy.

Cathepsin D (CD) is the principal lysosomal aspartate protease and a main endopeptidase responsible for the degradation of long-lived proteins $[9,10]$, including $\alpha$ syn[11]. CD is expressed widely in the brain, including the cortex, hippocampus, striatum, and dopaminergic (DA) neurons of the substantia nigra $(\mathrm{SNr})[12]$. CD is synthe- sized as a precursor with a signal peptide cleaved upon its insertion into endoplasmic reticulum[13]. The CD zymogen is activated in an acidic environment by cleavage of the pro-peptide. $\mathrm{CD}$ is also up-regulated in $\mathrm{AD}$ brains as an early event, but whether CD up-regulation is coincidental, disease promoting, or compensatory is unclear[14].

CD gene (Ctsd) homozygous inactivation was reported to cause human congenital neuronal ceroid lipofuscinosis (NCL) with postnatal respiratory insufficiency, status epilepticus, and death within hours to weeks after birth[15]. These patients had severe neurological defects at birth and neuronal $\alpha$-syn accumulation was not examined. Another patient with significant loss of CD enzymatic function (7.7\% Vmax from patient fibroblast lysates compared to controls) due to compound heterozygous missense mutations developed childhood motor and visual disturbances, cerebral and cerebellar atrophy, and progressive psychomotor disability[16]. Conceivably, milder forms of CD deficiency could predispose to late onset neurodegenerative disorders, including AD and PD. Parkinsonism has been noted in lysosomal tripeptidyl peptidase I deficient patients[17], adult forms of NCL patients[18], and Gaucher disease patients[19]. $\alpha$-syn aggregation has been reported in both neurons and glia in several lysosomal disorders, such as Gaucher disease[20], Niemann-Pick disease[21], GM2 gangliosidosis, Tay-Sachs, Sandhoff disease, metachromatic leukodystrophy, and beta-galactosialidosis[22].

Significant $\alpha$-syn accumulation has not been previously reported in mouse models of proteolytic disorders involving proteasomes, autophagy or other lysosomal proteases [23-26]. Here we report a robust $\alpha$-synucleinopathy in CD deficient mice, despite the compensatory up-regulation of other lysosomal proteases, and the absence of an increase of $\alpha$-syn mRNA expression. We found that proteasome activities are significantly reduced in the CD-deficient brain, whereas several key UPS factors are either normal or up-regulated, indicating crosstalk between lysosomal and proteasomal activities at the levels of signaling rather than a reduction of protein levels. Finally, we demonstrate that CD, but not Cathepsin B (CB) or Cathepsin L (CL), overexpression reduces $\alpha$-syn aggregation and provides potent neuroprotection from $\alpha$-syn-induced neuron death in vitro and in vivo.

\section{Results \\ $C D$ deficient mice exhibit extensive accumulation of $\alpha$-syn in neurons}

To investigate the involvement of lysosomal functions in $\alpha$-syn clearance, we analyzed mice deficient in CD, previously generated by a targeted insertion of the neo marker in exon 4[27]. CD-deficient (Ctsd-/-) mice die at approxi- 
mately postnatal day 26 (p26) due to a combination of nervous system and systemic abnormalities. Extensive neuron death resulting from activation of both apoptotic and non-apoptotic pathways has been observed in these mice [27-31]. We examined brains from p21 and p25 Ctsd-/- mice and found significant $\alpha$-syn accumulation in neuronal cell bodies in p25 Ctsd-/- but not wildtype cortex (Fig. 1a). In contrast to the brains of human lipidoses patients[32] where $\alpha$-syn aggregates are found in both neurons and glia and co-localize with lipids, in Ctsd-/brains $\alpha$-syn accumulations do not co-localize with autofluorescent lipofuscin (data not shown).

Furthermore, $\alpha$-syn accumulations in Ctsd-/- brains were present in cells co-expressing the neuron marker, neuronal nuclear antigen (NeuN), but not in glial fibrillary acidic protein (GFAP)-immunoreactive astrocytes (Fig. $1 \mathrm{~b}-\mathrm{c})$. Accumulation of ubiquitinated proteins also occurs in Ctsd-/- cortex (Fig. 1a). A relatively small fraction of neurons ( $\sim 5 \%)$ with intense accumulated $\alpha$-syn immunostaining also exhibit co-localization with intense accumulated ubiquitin staining, consistent with the observation that a small fraction of $\alpha$-syn in LB is ubiquitinated [33-36]. Correspondingly, we found elevated levels of high molecular weight but not monomeric $\alpha$-syn, and high molecular weight ubiquitinated proteins in both TritonX-100 soluble and insoluble extracts from the cortex of Ctsd-/- mice by western blot analyses compared to Ctsd+/+ mice, similar to what occurs in LB diseases (Fig. $1 \mathrm{~d}-\mathrm{e})$. Truncated $12 \mathrm{kDa}$ and $10 \mathrm{kDa} \alpha$-syn fragments are reduced in Ctsd-/- extracts (Fig. 1d-e).

Antibody pulldown experiments indicate that a small fraction of accumulated $\alpha$-syn in Ctsd-/- brains is mono-ubiquitinated (Fig. 1f). These results are consistent with a small fraction of accumulated $\alpha$-syn in Ctsd-/- brains being mono-ubiquitinated [33-36]. Ubiquitin immunostaining is present in nearly all neurons with variable intensity. 5\% of those neurons with intense accumulated ubiquitin staining also exhibit intense accumulated $\alpha$-syn immunostaining in Ctsd-/- brain sections. Conversely, 5\% of neurons with intense accumulated $\alpha$-syn immunostaining also exhibit intense accumulated ubiquitin staining. p21 Ctsd+/+ and Ctsd-/- brains do not exhibit considerable difference in $\alpha$-syn immunostaining intensity or protein level by western blot analyses. However, ubiquitin accumulation occurs as early as p21 in Ctsd-/cortical extracts compared to wildtype cortical extracts (Fig. 1g).

Immunostaining with synphilin antibodies have not detected "aggregation-like" structures in the cell body where $\alpha$-syn is. Nor did we observe increased synphilin in western blot analyses. Thus the $\alpha$-syn accumulation is unlikely to be induced by synphilin accumulation in Ctsd-
/- brains. The cytoplasmic microtubule-associated protein, tau, did not accumulate in Ctsd-/- cortex at p25 compared to wildtype cortex at p25 (data not shown), suggesting that $\mathrm{CD}$ deficiency does not have a general effect on the accumulation of all cytoplasmic proteins.

In human LB, 95\% of the insoluble $\alpha$-syn is phosphorylated $[33-35,37,38]$. We found that anti-phospho- $\alpha$-syn antibody (from Dr. Iwatsubo $[33,36,38]$ ) did not recognize the intensely immunoreactive accumulated $\alpha$-syn in Ctsd-/- brains, although numerous neurons in both wildtype and Ctsd-/- brains exhibited labeling with this antibody. Whether this antibody lacks specificity when used in mouse brain sections or the accumulated $\alpha$-syn in Ctsd-/- brain is simply not phosphorylated cannot be determined from this immunohistochemical study. Western blot analyses indicate that a few immunoreactive bands are increased in Ctsd-/- extracts compared to wildtype extracts.

\section{Intense $\alpha$-syn immunoreactive accumulations are outside of autophagosomes and lysosomes in affected neurons}

Prior studies found autophagosomes start to accumulate in Ctsd-/- brains as early as p1, compared to Ctsd+/+ agematched controls $[28,30]$. Furthermore, CB immunostaining as well as enzymatic activities are increased as early as p 21 in Ctsd-/- brains [28,30]. Electron microscopy studies demonstrated that $\mathrm{CB}$ was associated with irregularly shaped and membrane-bound structures containing electron-dense materials, characterizing them as lysosomes in Ctsd-/- brains $[28,30]$. We found that $\alpha$-syn accumulation does not become prominent until near p25 in Ctsd-/- brains. $\alpha$-syn accumulation occurs in only a subpopulation of neurons that exhibit enhanced Atg8 (AuTophaGy8)/LC3 (light chain 3) staining, indicating that $\mathrm{AV}$ accumulation precedes $\alpha$-syn accumulation (Fig. $2 a)$. We also found that $\alpha$-syn accumulations are adjacent to, but do not overlap with, immunoreactivity for the AVassociated protein Atg8/LC3 or the lysosomal associated protein $\mathrm{CB}$, suggesting that $\alpha$-syn accumulation formed outside of autophagosomes and lysosomes (Fig. 2b). Neuronal populations immunoreactive for the apoptotic marker, cleaved caspase-3, are distinct from those with intense $\alpha$-syn accumulation (Fig. 2c).

\section{$\alpha$-syn accumulation is not due to up-regulation of its mRNA, and appears despite compensatory up-regulation of other proteases}

While bulk protein degradation appears to be normal in Ctsd-/- mice[27], we found that $\alpha$-syn mRNA is down-regulated in Ctsd-/- brains at p25 when $\alpha$-syn accumulation occurs (Fig. 3a). This is consistent with the finding that $\alpha$ syn mRNA is either unchanged or down-regulated in the majority of sporadic PD cases[39], indicating that $\alpha$-syn accumulation is unlikely to be the consequence of ele- 

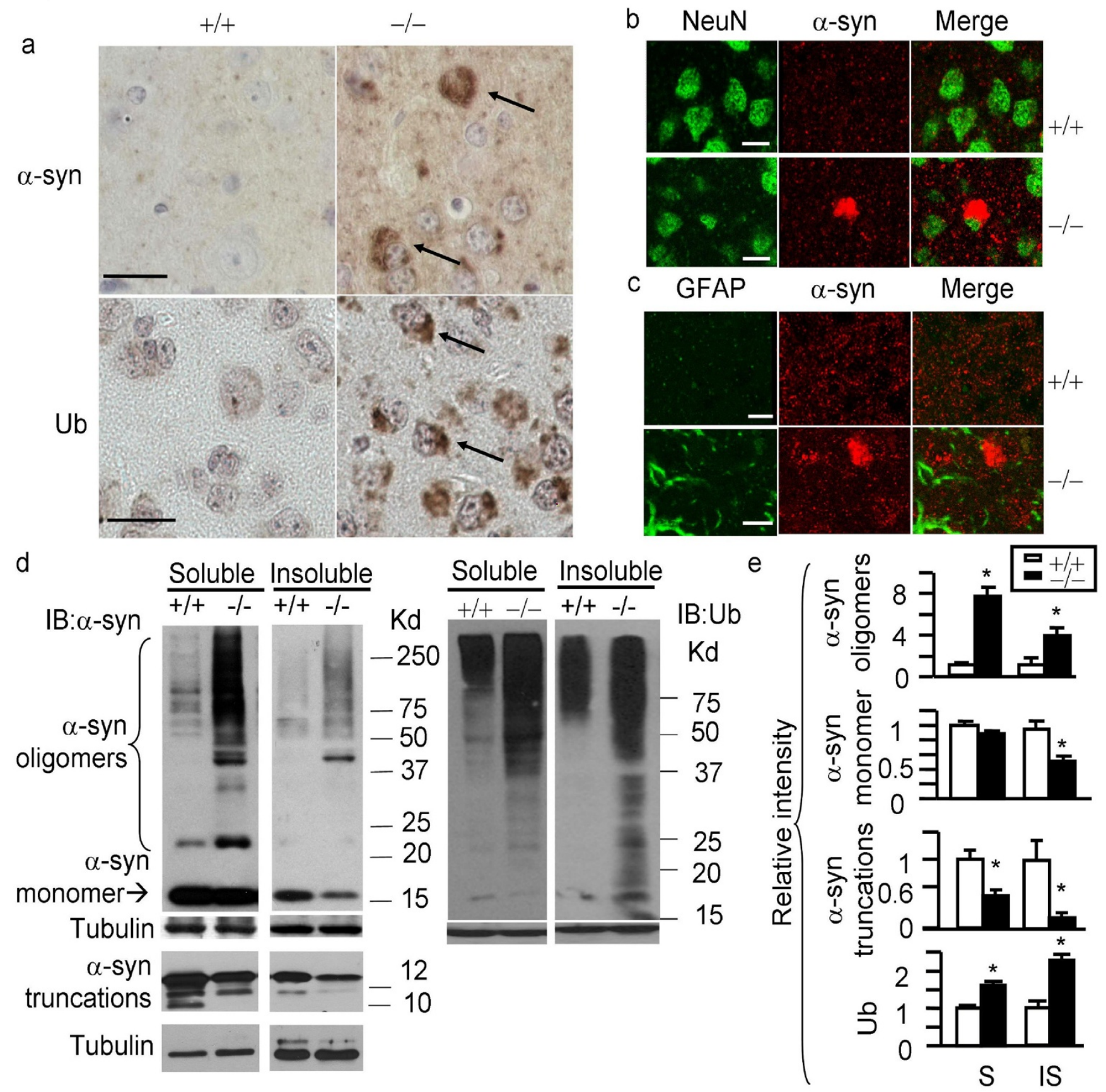

Figure I (see legend on next page) 
Figure I (see previous page)

$\alpha$-syn accumulates in neuronal cell bodies in p25 Ctsd-/- cortex. a. Immunohistochemical detection of $\alpha$-syn and ubiquitin in p25 Ctsd+/+ (+/+) and Ctsd-/- (-/-) cortex. Scale bar = 20 micron. Arrows point to intense $\alpha-s y n$ and ubiquitin immunoreactive cells. b. $\alpha$-syn accumulation occurs in $\mathrm{NeuN}+$ neuronal cell bodies. $\alpha$-syn $=$ Cy3 (red), NeuN = FITC (green).

Wildtype $(+/+)$ brains exhibit diffuse $\alpha$-syn staining consistent with a synaptic distribution. Ctsd-/- brains showed neurons with cytoplasmic accumulation of $\alpha$-syn immunoreactivity. Scale bar $=10$ micron. c. $\alpha$-syn does not exhibit pronounced accumulation in GFAP+ cells. $\alpha$-syn = Cy3 (red). GFAP = FITC (green). Scale bar = 10 micron. d. Accumulation of high molecular weight $\alpha$-syn and ubiquitinated proteins in both the TritonX-100 soluble and the insoluble fractions of the Ctsd-/- mice. Intensity of $\alpha$ syn monomer, $\alpha$-syn oligomers, and Ub-positive smears were quantified and compared between Ctsd+/+ and Ctsd-/- extracts. Truncated $12 \mathrm{kDa}$ and $10 \mathrm{kDa} \alpha$-syn fragments are reduced in Ctsd-/- extracts. e. Quantification of the western results. $\mathrm{n}=3$ mice each genotype. ${ }^{*} p<0.05$ compared to $C t s d+/+$ by Student t-test. $S=$ TritonX-I 00 soluble. IS $=$ TritonX- 100 insoluble. $\mathrm{f}$. A small fraction of accumulated $\alpha$-syn in Ctsd-/- brains being mono-ubiquitinated. Western blot analysis of TritonX-I00 soluble Ctsd-/- brain extract (Input), pulldown product by a polyclonal $\alpha$-syn antibody C-20 (Santa Cruz) (middle lane), and pulldown product by a same-isotype control antibody $(\mathrm{lgG})$. Immunoblot was probed with mAbI5I 0 against ubiquitin. Shown are the 25 $\mathrm{kDa}$ bands of ubiquitin immunoreactivity that were pulled down by the C-20 anti- $\alpha$-syn antibody. g. Western blot analysis of ubiquitin with $\mathrm{p} 2 \mathrm{I} C t s d+/+$ and $C t s d-/$ - cortical extracts. The intensity of each lane was quantified and shown in the bar graph. ${ }_{p} p$ $<0.05$ Student t-test. h. Western blot analyses of Cts $d+/+$ and Ctsd-/- cortical extracts, together with human DLB brain extracts using anti-phospho- $\alpha$-syn antibody provided by Dr. Iwatsubo $[33,36,38]$. Arrows indicate positions of immunoreactive bands that are increased in Ctsd-/- mice and the position of $\alpha$-syn monomer.

vated gene expression. Prior studies reported that CB but not CL protein is up-regulated in Ctsd-/- brains at p23[28]. To better understand the role of $\mathrm{CD}$ in selective protein degradation and PD, we analyzed the expression of genes encoding other brain-enriched lysosomal proteases, autophagy-associated factors, proteasome subunits, and genes linked to familial PD. Interestingly, genes encoding other lysosomal cathepsins B, L, F and H (Ctsb, Ctsl, Ctsf, and Ctsh) mRNAs are all up-regulated at p25 (Fig. 3a). This result may suggest a common transcription regulatory mechanism for these cathepsins in response to CD deficiency. Alternatively, the influx of macrophages or microglia into the Ctsd-/- brain at this age may lead to an increase in cathepsin mRNA expression[40]. We also determined that accumulation of autophagosomes in Ctsd-/- neurons is accompanied with transcriptional upregulation of $A \operatorname{tg} 7$ but not $A \operatorname{tg} 12$ (Fig. 3a). Both Atg7 and Atg12 are involved in an ubiquitin-like activity important for autophagosome expansion. Up-regulation of Atg7 may indicate an increase of autophagosome production in addition to a blockade of autophagy completion $[28,38,40]$. mRNA of Park2 which encodes Parkin, mutation of which has been found in a subset of autosomal recessive $\mathrm{PD} ; U C H L 1$, mutation of which has been found in a subset of autosomal dominant PD; and Psmb7 which encodes proteasome $20 \mathrm{~S}$ core $\beta 2$ subunit are also modestly up-regulated in response to CD deficiency, indicating a compensatory response to $\mathrm{CD}$ deficiency at the level of gene transcription (Fig. 3a).

\section{$C D$ deficiency reduces proteasome activities}

In addition to deficient macroautophagy, we found an accumulation of GAPDH, a substrate of CMA (Fig. 3b). Interestingly, we also found reduced proteasome activity in Ctsd-/- brain extracts (Fig. 3c), suggesting a functional interaction between the two major $\alpha$-syn clearance machineries, lysosomes and proteasomes. Accumulation of ubiquitinated proteins in Ctsd-/- brain appears at p21 compared to that in wildtype brains (Fig. 1g, 3e), when proteasome activities are unaltered as determined by the proteasome activity assay (data not shown). So far, none of the proteasome-related proteins we examined, including UCHL1, a gene mutated in familial PD and a ubiquitin hydrolase and E3 ligase; Usp14, a key deubiquitination enzyme; Rpt3, an ATPase regulatory subunit, a4 subunit that is important for the gating into the 20S core particle, and b1 subunit that is part of the proteasome core, were significantly changed as determined by western blot analyses in Ctsd-/- brains (Fig. 3d).

\section{Overexpression of $C D$ reduces $\alpha$-syn aggregation in mammalian cells}

To further understand how CD activity influences $\alpha$-syn homeostasis, we examined whether enhancing CD expression can reduce $\alpha$-syn aggregation. We adopted the simple culture system developed by McLean and colleagues in which an $\alpha$-syn-green fluorescent protein (GFP) fusion protein ( $\alpha$-syn-GFP) forms visible aggregates in cells when co-expressed with synphilin[41]. We transfected H4 neuroglioma cells with $\alpha$-syn-GFP, synphilin, and CD. As a control, cells were transfected with $\alpha$-syn-GFP, synphilin and empty vector pcDNA3.1. Approximately 50\% of control transfected cells exhibited $\alpha$-syn aggregates, consistent with published findings[41]. Remarkably, transfection of CD together with $\alpha$-syn-GFP and synphilin led to less than $20 \%$ of transfected cells exhibiting $\alpha$-syn aggregates (Fig. 4a). To address the issue of whether CD could affect synphilin levels, we performed immunocytochemistry 
a

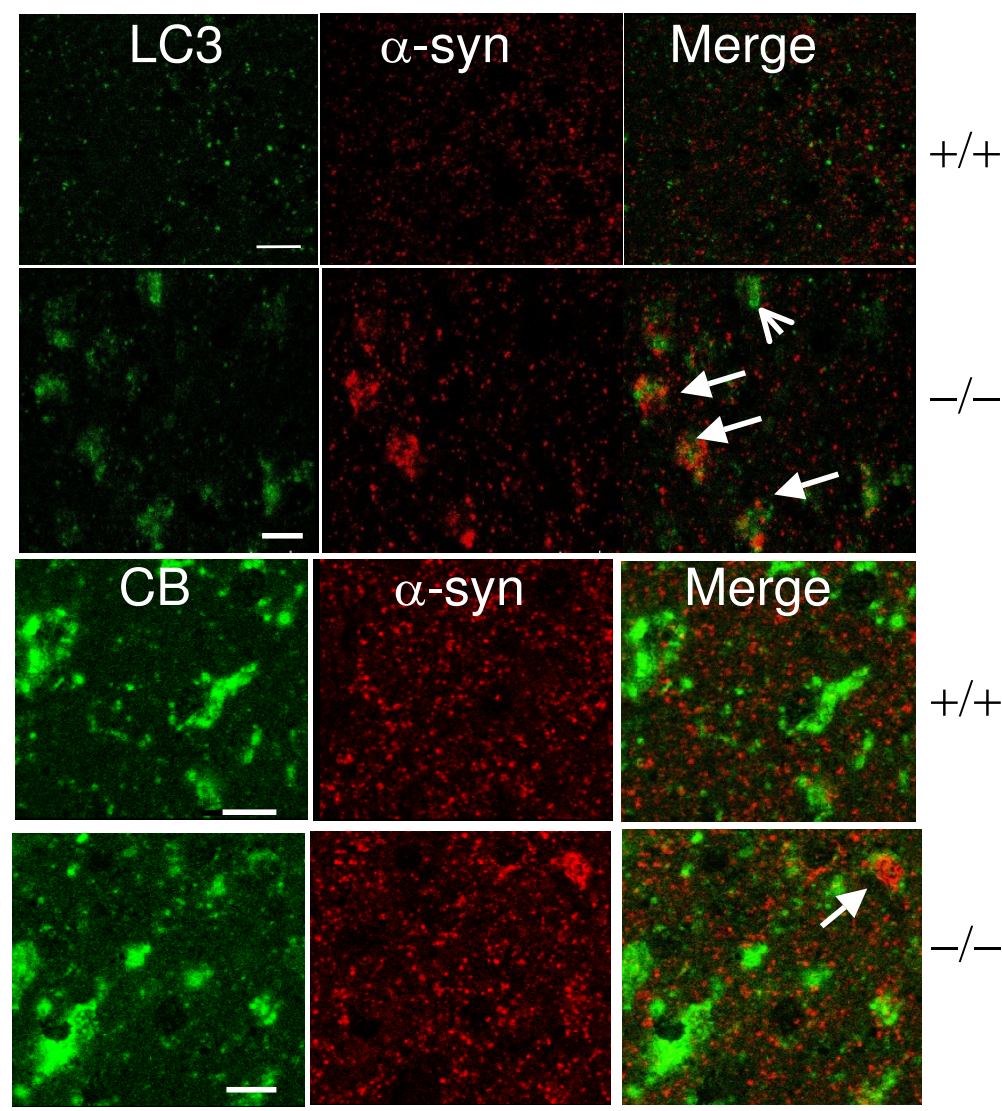

C

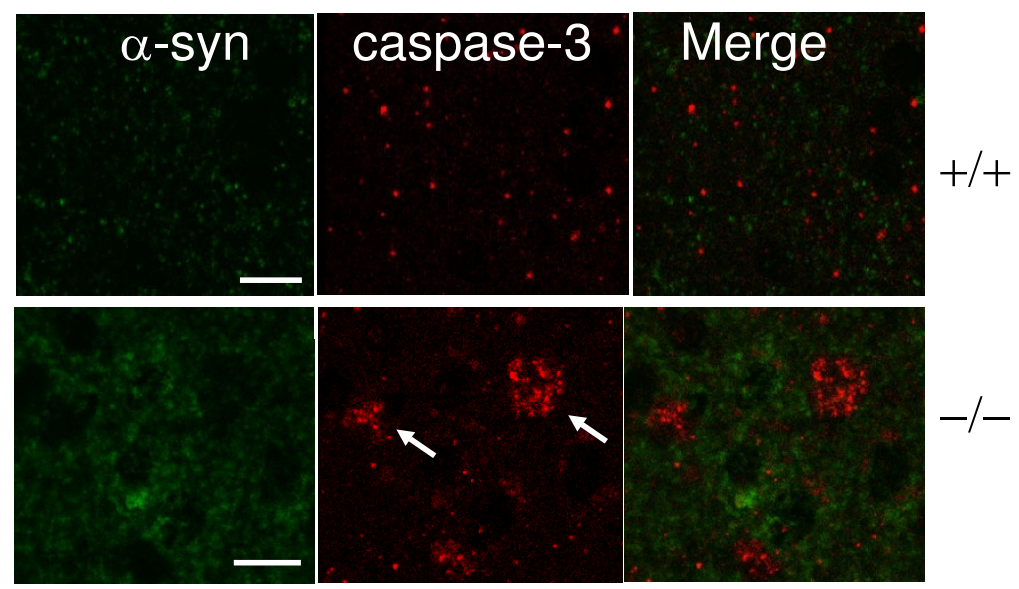

Figure 2

$\alpha$-syn accumulation does not co-localize with LC3 or CB immunoreactivity and is independent of active caspase-3 immunoreactivity. a. Immunostaining with Atg8/LC3 and $\alpha$-syn antibodies shows that LC 3 staining is increased in Ctsd-/- mice compared to Ctsd+/+ mice, and intense $\alpha$-syn immunoreactivity does not colocalize with LC3 immunoreactivity (arrows, p25). LC3 = FITC (green). $\alpha$-syn = Cy3 (red). Arrowheads point to cells with high LC3 immunoreactivity but without intense $\alpha$-syn immunostaining. b. $\alpha$-syn accumulation does not overlap with CB immunoreactivity. CB $=$ FITC (green). $\alpha$-syn $=$ Cy3 (red). Arrow points to $\alpha$-syn intense immunoreactive staining adjacent to CB staining. $c$. Neurons with active caspase- 3 immunoreactivity do not exhibit intense $\alpha$-syn immunoreactivity in Ctsd-/- brains. $\alpha$-syn $=$ FITC (green). Active caspase-3 = Cy3 (red). Arrows point to active caspase-3 immunoreactivity. Scale bar $=10$ micron. $n=3$ mice each genotype. 


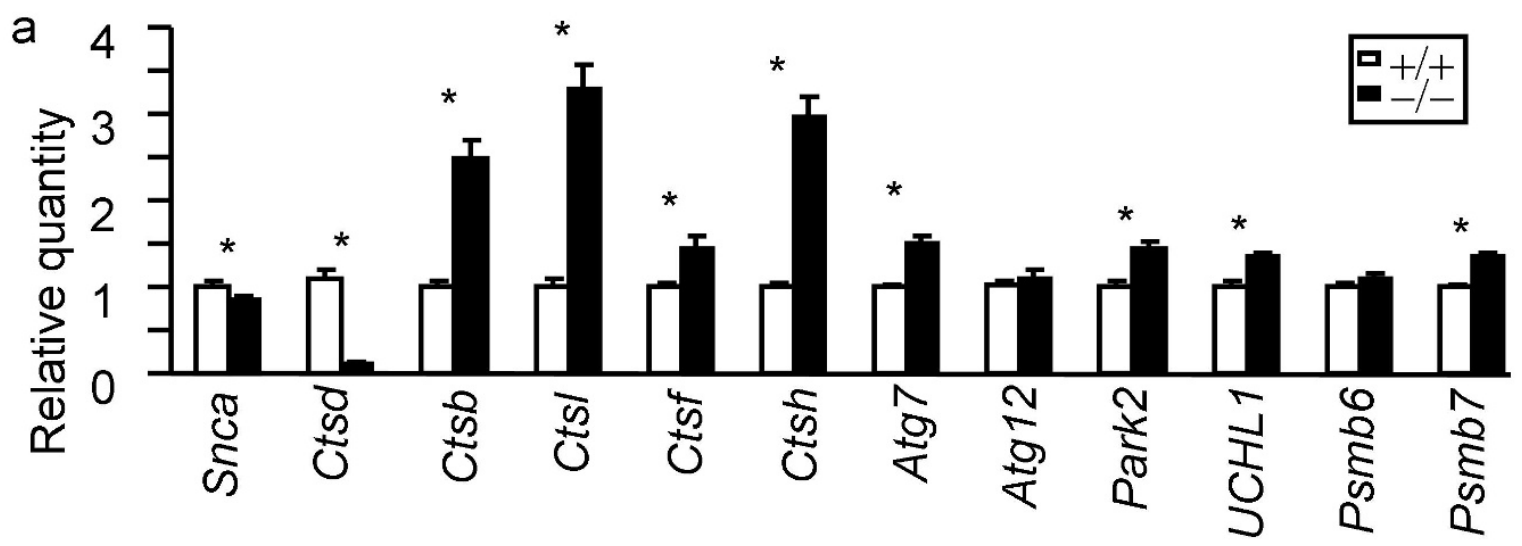

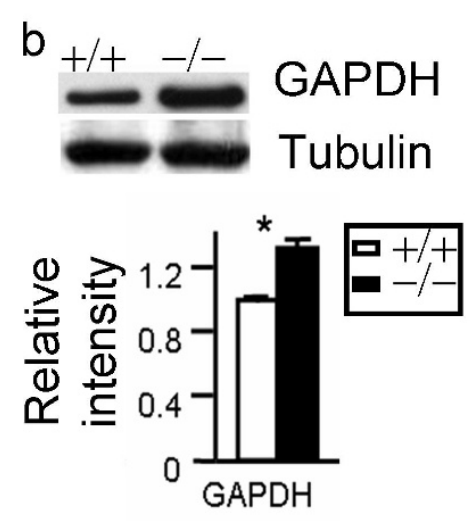

d

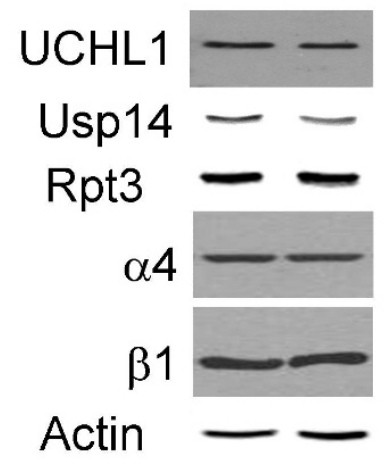

C

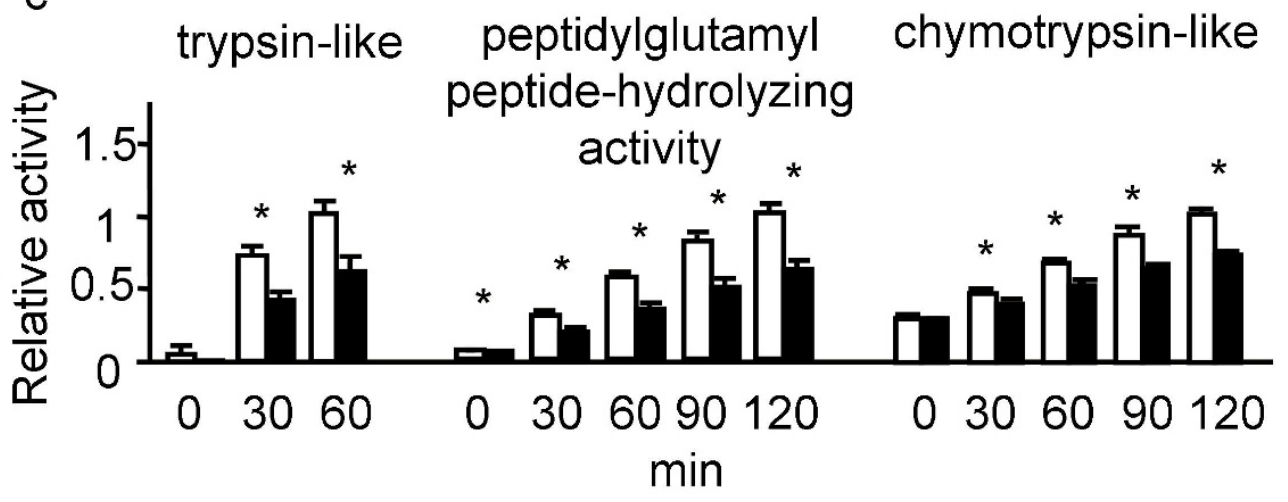

e

Accumulation of AVs

Accumulation of Ub-protein

Increase of $\mathrm{CB}$

Caspase-3 activation

Accumulation of GADPH

Deficit of proteasomes

$\alpha$-syn aggregates p1 p21 p25

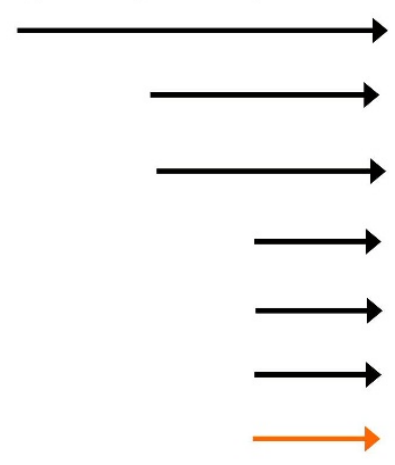

\section{Figure 3}

Deficits of proteasomes in CD deficient mice. a. $\alpha$-syn (Snca) mRNA is down-regulated in CD deficient brains compared to wildtype control brains. Ctsb, Ctsl, Ctsf, Ctsh, Atg7, UCHLI, Park2, and Psmb7 mRNA levels are up-regulated. Atg 12 and Psmb6 mRNA levels appear to be normal. b. Western blot analyses show an increase of steady state GAPDH, a CMA substrate. $n=3$ p25 brain. ${ }^{*} p<0.05$ by Student t-test, compared between $C t s d+/+$ and Ctsd-/- brains. c. Extracts from Ctsd-/- cortex exhibit reduced proteasome activities compared to $C t s d+/+$ as indicated by assays with trypsin-like fluorigenic substrate (VGR-AMC, reaching maximum at $60 \mathrm{~min}$ ), chymotrypsin-like fluorigenic substrate (Z-GGL-AMC, reaching maximum at 120 min), and peptidylglutamyl peptide-like fluorigenic substrate (Suc-LLVY-AMC, reaching maximum at I 20 min). The activities that are inhibitable by the proteasome inhibitor lactacystin were quantified. $n=3$ mice each genotype. * $p<0.05$ by Student $t$-test. d. Normal expression of proteins involved in UPS. Western blot analyses of UCHLI, Usp I4, Rpt3, $\alpha 4$ and $\beta$ I indicate that these UPS factors are expressed normally in Ctsd+/+ and Ctsd-/- cortical extracts. Actin immunoblotting was used as a loading control. $n=3$ mice each genotype. e. A diagram regarding onset of relative pathologies. 

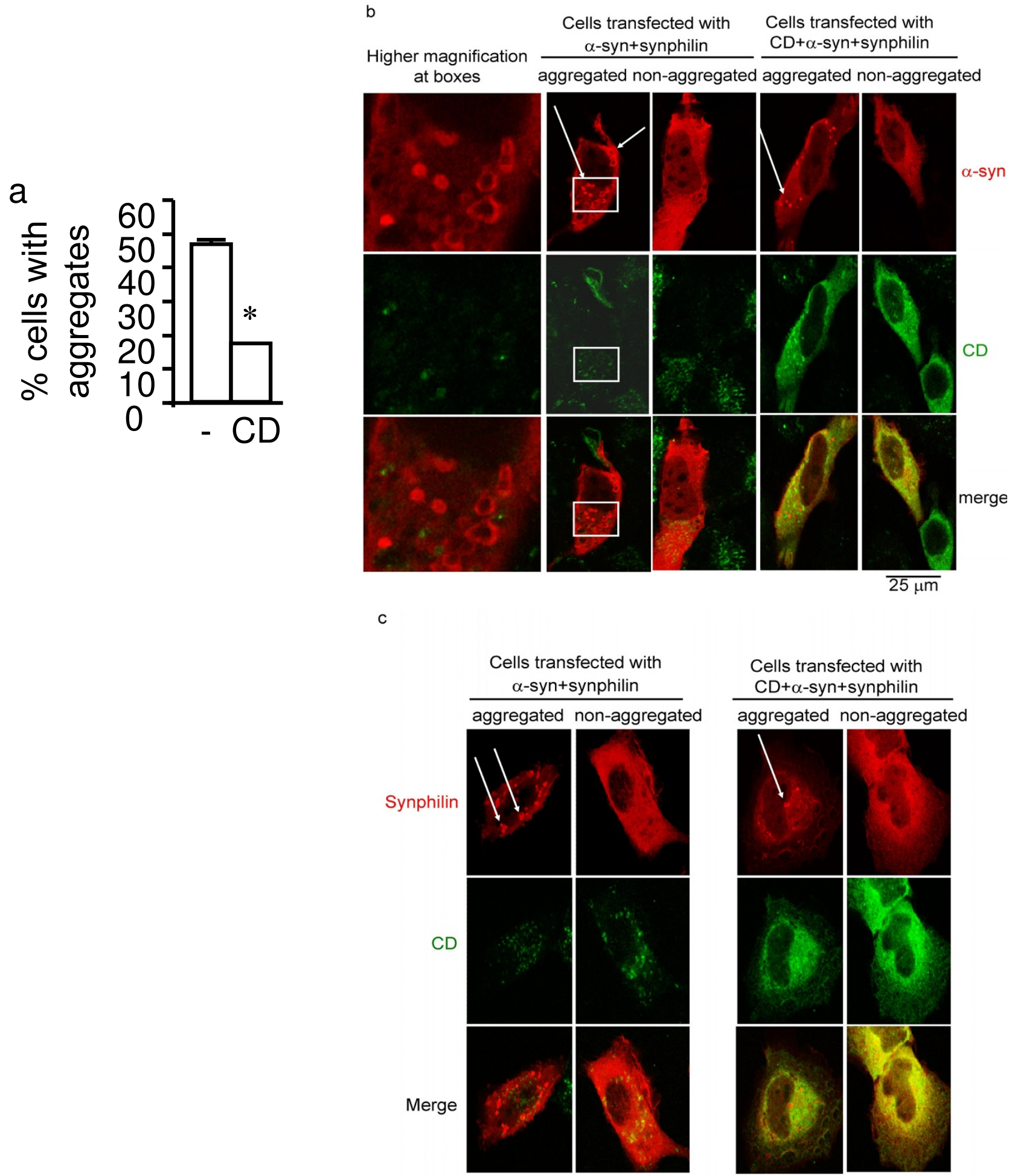

Cells transfected with CD $+\alpha$-syn+synphilin

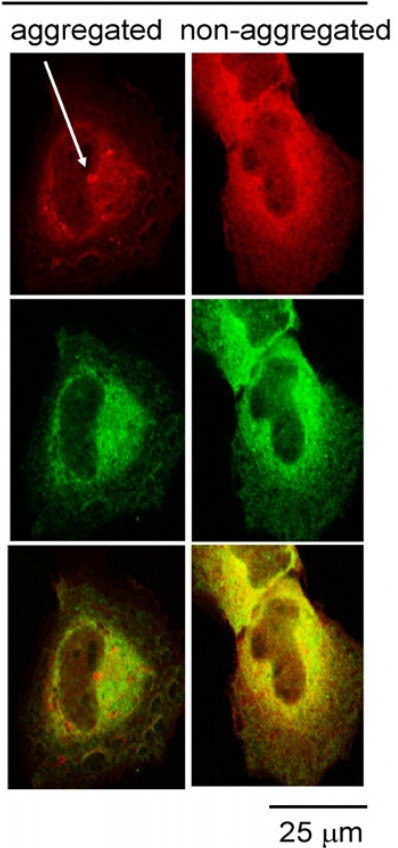

Figure 4 (see legend on next page) 
Figure 4 (see previous page)

CD reduces $\alpha$-syn aggregation. a. CD reduces $\alpha$-syn aggregation in an aggregation assay. $50 \%$ of the cells transfected with $\alpha$-syn-GFP, synphilin and empty vector exhibited visible $\alpha$-syn aggregates. Co-transfection of CD together with $\alpha$-syn-GFP and synphilin reduced the number of cells with visible $\alpha$-syn aggregates to $20 \% . n=3$ independent transfection, each in quadruplicate. ${ }^{*} p<0.05$ compared to absence of exogenous CD by Student t-test. b. Double immunostaining for CD and $\alpha$-syn in the aggregation assay after transfection of $\mathrm{H} 4$ cells with $\alpha$-syn+synphilin+vector and $\alpha$-syn+synphilin+CD. Many more cells transfected with synphilin $+\alpha$-syn+vector have $\alpha$-syn aggregates than cells transfected with synphilin $+\alpha-$ syn $+C D$. $\alpha$-syn $=$ red; $C D=$ green. Higher magnification images of the boxed areas are shown at the left-most panel. $\alpha$-syn aggregates tended to be found in cellular areas with low levels of CD staining, in $\mathrm{H} 4$ cells with either $\alpha$-syn+synphilin+vector or $\alpha$-syn+synphilin+CD. Scale bar $=25$ micron. Arrows point to $\alpha$-syn aggregates. c. Double immunostaining for $C D$ and the V 5 tag of synphilin in the aggregation assay after transfection of $\mathrm{H} 4$ cells with $\alpha$-syn+synphilin+vector and $\alpha$-syn+synphilin+CD. Many more cells transfected with synphilin $+\alpha$-syn+vector have $\alpha$-syn aggregates than cells transfected with synphilin $+\alpha-$ syn $+C D$. Synphilin $=$ red; $C D=$ green. The levels of synphilin immunostaining were indistinguishable in cells transfected with synphilin+ $\alpha-$ syn+vector versus cells transfected with synphilin $+\alpha-s y n+C D$. This is true in cells with or without aggregates. Scale bar $=25$ micron. Arrows point to $\alpha$-syn aggregates.

experiments to compare $\alpha$-syn+synphilin+vector transfected cells and $\alpha$-syn+synphilin+CD transfected cells. We chose this approach because very low transfection efficiency was achievable (less than 5\%) in this aggregation assay. Thus, we cannot perform western blot analyses or quantitative RT-PCR assays for this experiment. Double immunostaining for CD and the V5 epitope tag on synphilin and double immunostaining for CD and $\alpha$-syn were performed (Figs. $4 \mathrm{~b}$ and $4 \mathrm{c}$ ). We quantified the number of transfected cells with $\alpha$-syn aggregates and those without $\alpha$-syn aggregates. Many more cells that were transfected with synphilin+ $\alpha$-syn+vector exhibited $\alpha$-syn aggregates in comparison to cells transfected with synphilin $+\alpha-s y n+C D$. Nonetheless, the levels of synphilin immunostaining were indistinguishable in cells transfected with synphilin+ $\alpha$-syn+vector versus cells transfected with synphilin $+\alpha-s y n+C D$. This is true in cells with or without aggregates. We conclude that $\mathrm{CD}$ reduction of $\alpha$-syn aggregation is unlikely to be secondary to a reduction in synphilin levels.

\section{Overexpression of CD is neuroprotective against $\alpha$-syn toxicity in mammalian cells}

Excessive $\alpha$-syn induces neuron death in cell cultures, and in a variety of genetic and viral delivery based animal models [42-45]. To examine the potential of elevating CD level as a means to reduce $\alpha$-syn-induced cell death, we transfected human neuroblastoma SHSY5Y cells with $\alpha$ syn-GFP, in the absence or presence of increased $C D$ expression (Fig. 5a). Similar to previous studies of $\alpha$-syn overexpression in yeast, worms and rat neurons[44], we found that overexpression of $\alpha$-syn-GFP induced significant cell death in SHSY5Y cells. Co-transfection of human CD provided significant protection against $\alpha$-syn-GFP overexpression-induced cell death (Fig. 5a). Quantitative real-time RT-PCR confirmed the up-regulation of $\alpha$-syn mRNA by $\alpha$-syn transfection, and lack of effect of CD transfection on $\alpha$-syn mRNA level (Fig. 5b). Furthermore, co-expression of CD with $\alpha$-syn-GFP in human neuroblastoma SHSY5Y cells produced a cleavage product of $\alpha$-synGFP and reduced endogenous monomeric $17 \mathrm{kDa} \alpha$-syn (Fig. 5c).

\section{$\alpha$-syn point mutation at the major CD cleavage site results in resistance to $C D$ neuroprotection}

$\alpha$-syn is rich in hydrophobic amino acids (52\%) and is natively unfolded. CD has a known specificity in recognizing hydrophobic residues[11]. Although $\alpha$-syn contains many putative CD cleavage sites, the main cleavage occurs at Y125[11]. We found that CD is also protective against PD-causing mutant $\alpha$-syn-GFP induced-cell death in SHSY5Y cells (Fig. 5d). In contrast, mutating $\alpha$-syn-GFP at the putative CD cleavage site Y125[11] results in an $\alpha$-syn mutant that induces cell death that resists neuroprotection by elevated CD (Fig. 5d). Furthermore, CD is ineffective at attenuating chloroquine- or staurosporine-induced cell death (Fig. 5d). Western blot analyses confirmed the up-regulation of transfected genes (Fig. 5e).

\section{Overexpression of $C D$ is neuroprotective in $\mathbf{C}$. elegans}

To further investigate the role of CD activity in $\alpha$-syn clearance in vivo, we generated transgenic C. elegans expressing a human $\alpha$-syn and GFP fusion protein in body wall muscle cells. In these worms, human $\alpha$-syn::GFP forms aggregates as worms develop and age (Fig. 6a). As in mammalian cells[46], co-expression of the worm TOR-2 protein chaperone ameliorated the formation of $\alpha$ syn::GFP aggregates (Fig. 6b). Importantly, this established a genetic background within which enhancement of $\alpha$-syn aggregation could be more readily visualized by RNA interference (RNAi). Using bacterial RNAi feeding to specifically target the C. elegans ortholog of Ctsd, we knocked down Ctsd in $\alpha$-syn::GFP + TOR-2 transgenic worms. RNAi targeting of Ctsd led to a return of fluorescent aggregates over time (Fig. 6c), and RNAi of Ctsd did not affect tor-2 mRNA levels as examined by real-time RT- 
a

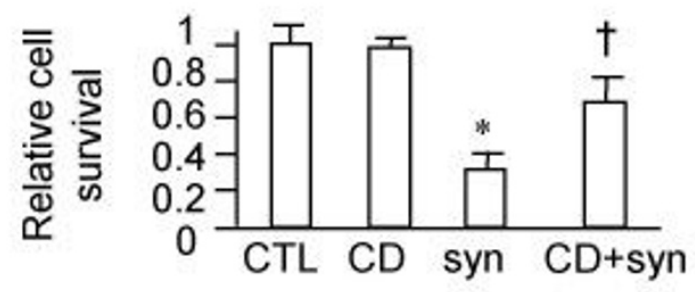

C

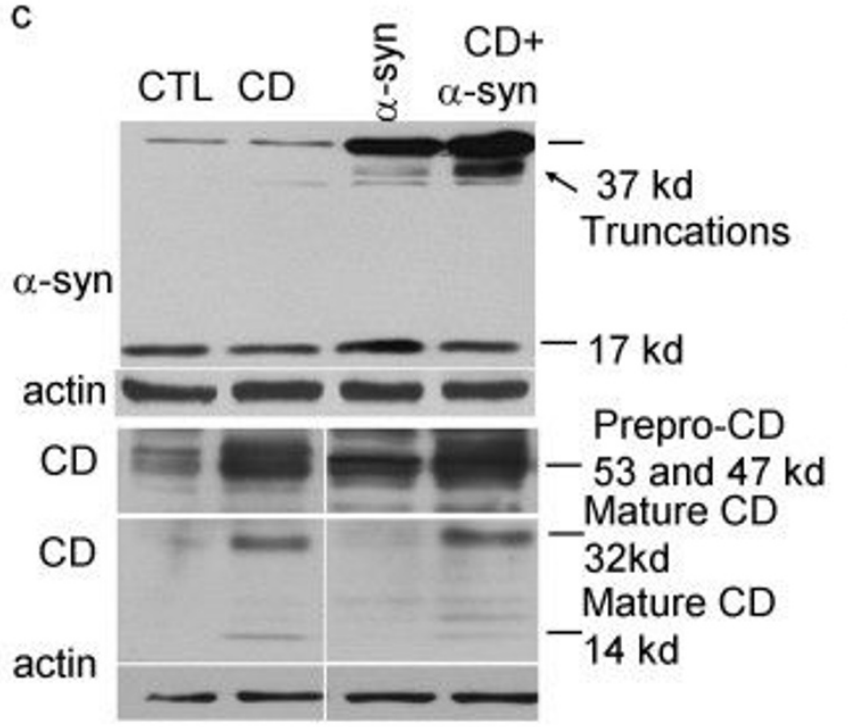

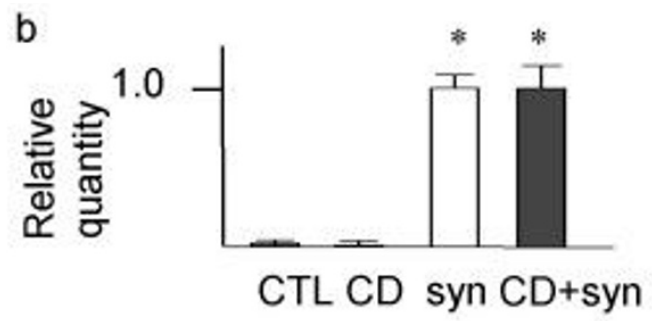

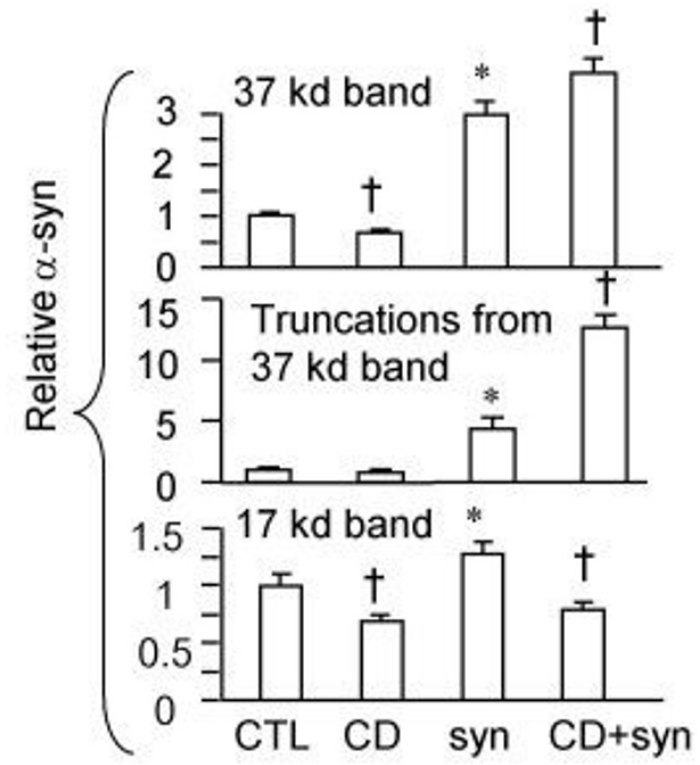

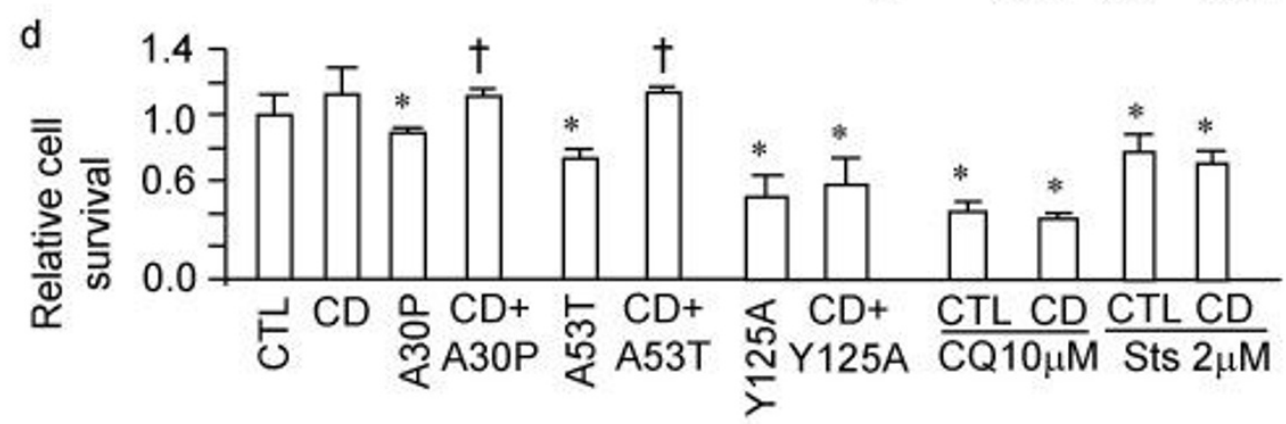

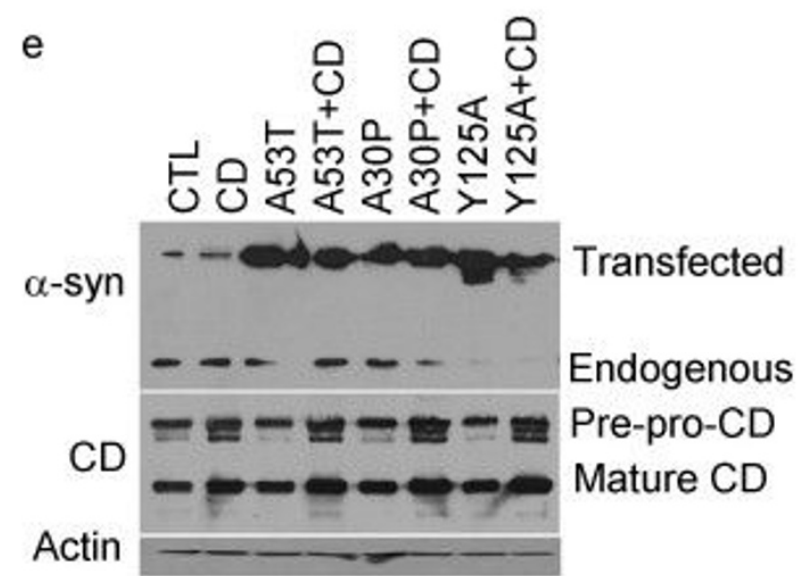

Figure 5 (see legend on next page) 
Figure 5 (see previous page)

CD reduces $\alpha$-syn toxicity. a. Enhanced CD expression protects against $\alpha$-syn overexpression-induced cell death. GFP was visualized under the fluorescence microscope and demonstrated more survival cells after co-transfection of GFP- $\alpha$-syn and CD compared to transfection with GFP- $\alpha$-syn alone. Viable cells were counted by trypan blue exclusion method. b. mRNA of $\alpha$ syn is unchanged by CD transfection. SHSY5Y cells were transfected with vector alone, CD, $\alpha-$ syn, or $\alpha-$ syn+CD. Paired Student t-tests were conducted on RQ values for each group to determine significance. $c$. Western blot analyses indicate that $C D$ transfection results in truncation of $\alpha$-syn-GFP (the appearance of a band below the full-length $37 \mathrm{kDa}$ band), and a reduction of endogenous $17 \mathrm{kDa} \alpha$-syn monomers. CD is synthesized as a prepropeptide $(53 \mathrm{kDa})$; the signal peptide is cleaved upon CD insertion into the endoplasmic reticulum $(47 \mathrm{kDa})$. The $\mathrm{CD}$ zymogen is then activated in the acidic lysosomal environment to produce the 32 and $14 \mathrm{kDa}$ products [13,47]. d. Enhanced CD expression reduces A53T and A30P mutant $\alpha$-syn-induced cell death, but does not reduce YI25A mutant $\alpha$-syn-, $10 \mu \mathrm{M}$ chloroquine-, or $2 \mu \mathrm{M}$ staurosporine-induced cell death. For a-d, * $p$ $<0.05$ compared to control $(C T L) ; \dagger p<0.05$ compared to otherwise identical transfection except without CD. $n=3$ transfection for each experimental conditions. Student t-test was used. e. Increased protein levels correlate with transfection of respective cDNAs. SHSY5Y cells were transfected with control vector, or respective cDNA in each lane. The respective antibodies used for the immunoblots are at the left side of the gel images. Mutated $\alpha$-syn-GFP were produced. CD transfection did not produce significant truncation intermediate products on the mutated $\alpha$-syn-GFP, suggesting that the protection against $\mathrm{A} 53 \mathrm{~T}$ and $\mathrm{A} 30 \mathrm{P}$ may be via alteration of their intracellular targeting rather than direct cleavage. CD $53 \mathrm{kDa}$ and $47 \mathrm{kDa}$ precursors and the $32 \mathrm{kDa}$ mature product are shown. Actin immunoblot was used as a loading control.

PCR (Fig. 6f). Thus, Ctsd deficiency led to $\alpha$-syn aggregation in both mice and worms.

We further investigated whether human $\mathrm{CD}$ attenuates the loss of dopaminergic neurons in a C. elegans model of $\alpha$ syn-induced neurodegeneration[44]. Overexpression of $\alpha$-syn led to DA neuron death, as evidenced by the finding that only $16 \%$ of $7 \mathrm{~d}$ old adult $\alpha$-syn expressing worms ( $\mathrm{n}$ $=270$ worms analyzed) displayed normal numbers of DA neurons (Fig. 6d, g). In contrast, co-overexpression of human CD significantly protected against DA neurodegeneration, since $30 \%$ of same-staged animals $(n=270)$ exhibited wildtype DA neurons (Fig. 6e, g; $p<0.001$, Fisher Exact Test). Overexpression of enzymatic mutants of CD (D295R and F229I) [16,47], or related human cathepsin gene products, $\mathrm{CB}$ or $\mathrm{CL}$, did not attenuate $\mathrm{DA}$ neuron death in this in vivo assay (Fig. 6g), thereby suggesting a specific role of $C D$ in neuroprotection against $\alpha$ syn-induced DA cell death, as well as an essential role of CD enzymatic activity in this neuroprotection.

\section{Discussion}

Our results demonstrate that CD deficiency leads to significant accumulation of $\alpha$-syn that is concentrated in neuronal cell bodies, despite the up-regulation of multiple lysosomal cathepsin genes. $\alpha$-synucleinopathy arises from CD dysfunction, either directly due to deficient proteolytic cleavage, and/or indirectly as a consequence of compromised proteasome activity. Most significantly, we further demonstrated that $\mathrm{CD}$ overexpression protects neurons from $\alpha$-syn aggregation and $\alpha$-syn-induced death both in mammalian cells and in C. elegans. These findings suggest that targeted CD therapy may inhibit or reverse LB disease-associated neuropathology.
The $\alpha$-syn accumulations in Ctsd-/- brains are neuronal and perinuclear. Although Ctsd-/- brain extracts exhibited increased immunoreactive protein species recognized by the anti-phospho- $\alpha$-syn antibody that specifically recognizes human LB[36], $\alpha$-syn accumulations in Ctsd-/brains could not be detected by this antibody that specifically recognizes human LB despite that they were successfully used in our hands to demonstrate LB-specific staining of human PD specimen (data not shown). Only $5 \%$ of neurons exhibited intense immunoreactivity for both $\alpha$-syn and ubiquitin suggesting their accumulation, an observation in accordance with that only a small fraction of $\alpha$-syn is ubiquitinated in human LB [33-36]. $\alpha$-syn accumulations are adjacent to but not overlapping with autophagosomal or lysosomal markers, suggesting an attenuation of these complexes and organelles in encircling accumulated $\alpha$-syn in the Ctsd-/- brains. Where $\alpha$ syn unfolds and forms oligomers, and whether $C D$ reduces a specific sub-population of $\alpha$-syn protofibrils or other small assemblies of $\alpha$-syn require further investigation.

$\alpha$-syn gene triplication is causative in a subset of $\mathrm{PD}$, which suggests that increasing $\alpha$-syn gene dosage promotes DA neuron death in these patients[1]. Overproduction of $\alpha$-syn via AAV delivery induces DA neuron death in rodents[45]. CD deficiency induced by aging, genetic polymorphism, or environmental toxins may predispose animals to an earlier onset of spontaneous neuron death, or exacerbate neurotoxin or $\alpha$-syn overproductioninduced DA neuron loss, in comparison to wildtype control mice. Furthermore, although Ctsd-/- mice die approximately p26 without apparent tau or beta amyloid accumulation in the brain (data not shown), we cannot 

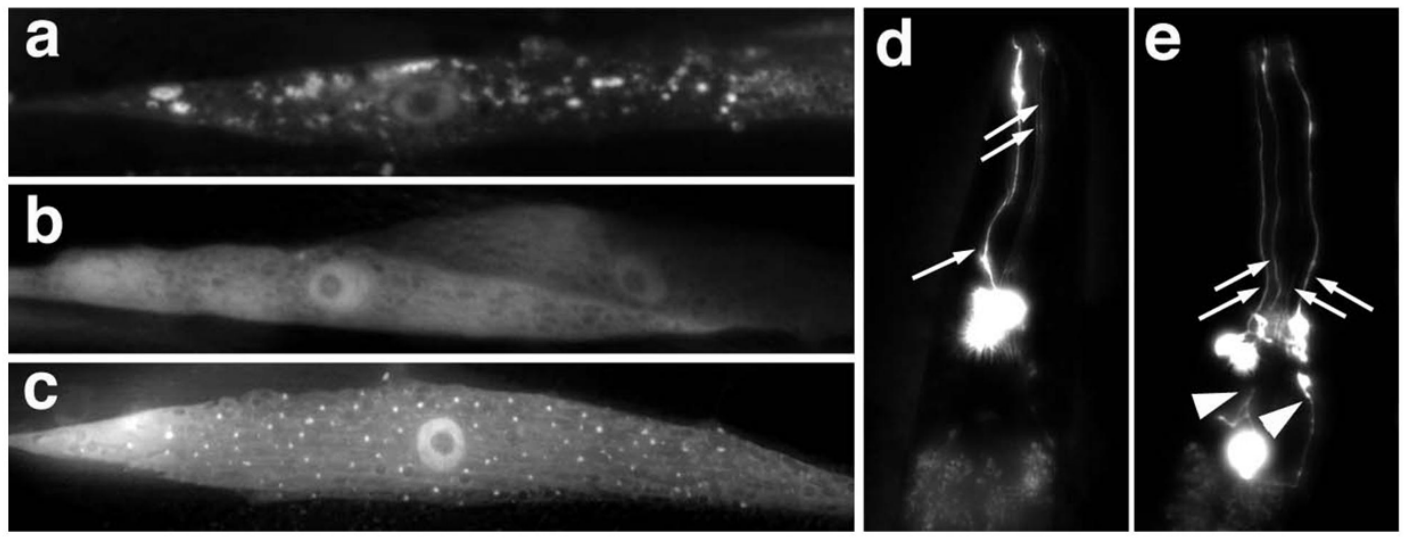

f
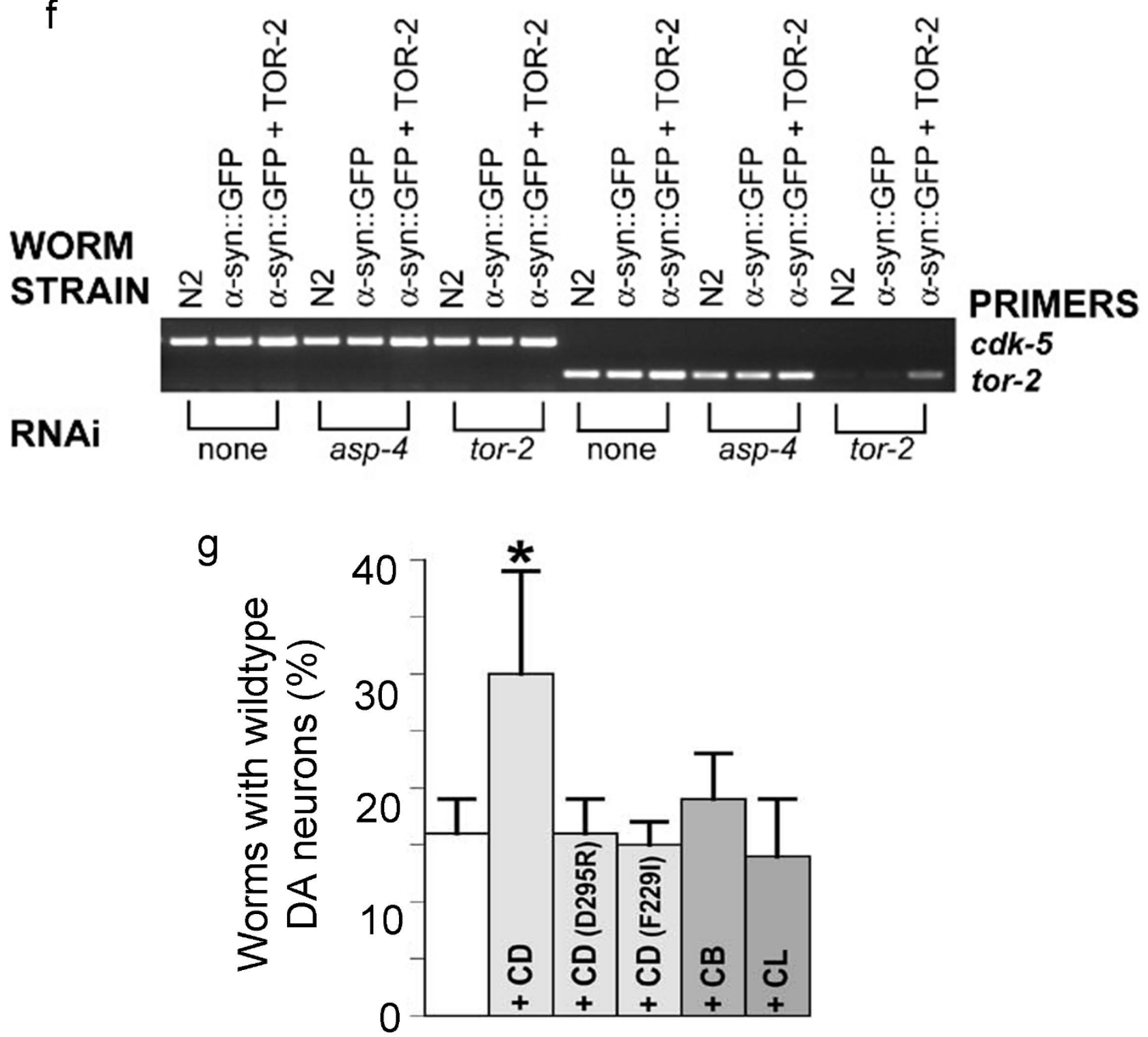

Figure 6 (see legend on next page) 
Figure 6 (see previous page)

Increased CD expression reduces $\alpha$-syn-toxicity in $C$. elegans. a. RNAi knockdown of a $C$. elegans $C$ tsd ortholog worsens aggregation of human $\alpha$-syn in vivo. Isogenic worm strain expressing $\alpha$-syn::GFP alone (a) or with TOR-2 (b), in body wall muscle cells of $C$. elegans. The presence of TOR-2, a protein with chaperone activity, attenuates the misfolded $\alpha$-syn protein (b). When worms expressing $\alpha$-syn::GFP + TOR-2 are exposed to CD RNAi, the misfolded $\alpha$-syn::GFP returns (c). d-f. Overexpression of CD protects DA neurons from $\alpha$-syn-induced degeneration. Worm DA neurons degenerate as animals age. At the $7 \mathrm{~d}$ stage, most worms are missing anterior DA neurons of the CEP (cephalic) and/or ADE (anterior deirid) classes. $d$. Note the presence of 3 of 4 CEP DA neurons (arrows) and the absence of the 2 ADE neurons. e. Overexpression of CD protects worms from neurodegeneration whereby worms display all 4 CEP (arrows) and both ADE (arrowheads) neurons. f. RNAi knock down of asp-4 does not reduce tor-2 expression level. Semi-quantitative RT-PCR was performed by using primers to amplify cdk-5 (loading control) and tor-2. For all strains analyzed, normal (non-RNAi) condition was used as a negative control, and tor-2 RNAi was used as a positive control.g. The percentage of worms exhibiting the wildtype neuronal complement of all 6 anterior DA neurons (30\%) was significantly greater than animals without CD overexpression (I5\%). CD mutants (D295R and F229l), CB and CL, in transgenic worms overexpressing human CDNAs encoding these mutated CD or the representative lysosomal cysteine proteases, do not have the same effect as the wildtype CD in reducing $\alpha$-syn toxicity. ${ }^{*} p<0.00 \mathrm{I}$ compared to $\alpha$-syn alone, by Fisher Exact Test.

exclude the possibility that partial loss of CD may also affect tau or beta amyloid clearance.

We found significant down-regulation of proteasome activities in Ctsd-/- brains. The reduction of proteasome activity may be due to reduced expression of UPS regulators and proteasome subunits, inactivating post-translational modification of these proteins, or specific inhibitory signaling by the accumulated ubiquitinated proteins. Crosstalk between protein degradation pathways is potentially important in neurodegenerative disease pathogenesis since inhibition of proteasomes upregulates lysosomal enzymes[48], and enhancing proteasome function alleviates autophagy defects[49]. Furthermore, $\alpha$-syn overexpression in mammalian cells affects proteasome activity, macroautophagy as well as lysosomal functions[50]. Lysosomal storage disorders and lysosomal cysteine protease inhibitor E64 treatment were previously shown to down-regulate UCHL1[51], however, such is not the case in Ctsd-/- brains in our study, indicating a distinct mechanism of CD deficiency-induced proteasome dysfunction. GAPDH accumulation may be a consequence of impaired CMA[3], because Ctsd-/- cells are compromised in lysosomal function[3]. Alternatively, GAPDH elevation may represent an ultimately futile compensatory signal that elevates macroautophagy initiation as previously suggested in HeLa cells[52]. Additionally, GAPDH elevation may promote the formation of protein inclusions $[53,54]$.

The overproduction of $\alpha$-syn has been shown to cause cell death in many studies through a variety of mechanisms, including a compromise in synaptic vesicle function, the induction of ER stress, Golgi fragmentation, mitochondrial dysfunctions and proteasome dysfunction [44,5558]. However, cell death in these studies required massive overproduction of $\alpha$-syn. Even in these conditions, the challenge has been to determine whether the intermediate species of $\alpha$-syn are the most toxic to neurons. It remains possible that the $\alpha$-syn aggregates in sporadic PD are not causative to DA neuron death, but rather a compensatory activity to attenuate DA neuron death, or a mere bystander effect in DA neuron death. The comparison of different mutant forms of $\alpha$-syn in their propensity in forming fibrils and their toxicity was carried out in yeast and the rate of fibrillization did not positively correlate with toxicity[59]. $\alpha$-syn can interact with many other proteins[60], but whether these interactions elicit cytoprotective versus death-inducing effects remains to be elucidated. Other observations suggest that LB formation may be a mechanism to sequester toxic $\alpha$-syn species and thus exert a protective function [61-63]. Our observation that $\alpha$-syn accumulates in Ctsd-/- brains does not distinguish its role in promoting or attenuating death in Ctsd-/brains in vivo. We did not observe neurons with concurrent activation of caspase- 3 and $\alpha$-syn accumulation (Fig. 2 ). This may indicate that $\alpha$-syn accumulation and capase3 activation are with different time course. Alternatively, our observation may suggest that? certain forms of $\alpha$-syn accumulation induce non-apoptotic cell death, or even compensatory neuroprotection.

$\alpha$-syn knockout mice are resistant to MPTP-induced DA neuron death [64-66]. Reduction of $\alpha$-syn is neuroprotective in multiple animal models $[67,68]$. Regardless of the precise mechanism for CD deficiency induced $\alpha$-synucleinopathy, our finding that enhanced expression of CD is neuroprotective against $\alpha$-syn aggregation and toxicity, both in worms and in mammals, provides a basis for future investigation of whether delivery of CD to the central nervous system in animal models of LB diseases can help alleviate protein aggregation and toxicity, and thereby serve as a previously unexplored target for disease therapy. 


\section{Methods \\ Mice}

We genotyped littermates from $C t s d+/$ - breeding. We used $C t s d+/+, C t s d+/-$ and Ctsd-/- littermates on C57BL6 background for all experiments.

\section{Immunohistochemistry}

Brains were placed in Bouin's fixative overnight at $4{ }^{\circ} \mathrm{C}$ followed by paraffin embedding. $5 \mu \mathrm{m}$ thick sections were used for immunohistochemical studies. The following antibodies were used: mouse anti-NeuN (Chemicon), mouse anti- $\alpha$-syn (BD Transduction Lab), sheep anti- $\alpha$ syn (Chemicon), goat anti-CD (Santa Cruz), mouse antiGFAP (Chemicon), rabbit anti-Ub (Dako), mouse antiUb (FK2, Biomol), mouse anti-Ub (Chemicon, clone Ubi1), mouse anti-Ub (Zymed), mouse anti-synaptophysin (Chemicon), goat anti-cathepsin B (Santa Cruz), rabbit anti-active caspase 3 (Chemicon), and rabbit-antiGAPDH (Cell Signaling). Horseradish peroxidase conjugated donkey derived secondary antibodies were used at 1:2000 (Jackson ImmunoResearch). The sections were then incubated with tyramide signal amplification (TSA) plus detection solution with $\mathrm{Cy} 3$ or fluorescein tyramide according to the manufacturer's instruction (PerkinElmer Life Sciences), followed by bisbenzimide staining of DNA. For chromogenic immunohistochemistry, we incubated the sections with a biotinylated secondary antibody (Vector Laboratories) followed by ABC reagent (ABC kit, Vector Laboratories). We visualized the immunoreaction by treating the sections in $0.05 \%$ diaminobenzidine (DAB) with hydrogen peroxide. The images were taken using a Leica TCS SP5 confocal microscope or a Zeiss Axiocam CCD camera on a $100 \mathrm{~W}$ Axioscope bright field and fluorescence microscope.

\section{$\alpha$-syn aggregation assay}

We used the in vitro system developed by McLean and colleagues in which an $\alpha$-syn-green fluorescent protein (GFP) fusion protein ( $\alpha$-syn-GFP) becomes truncated at the C-terminus, cleaving off GFP, to form visible aggregates in cells when co-expressed with synphilin[41]. We transfected H4 neuroglioma cells with $\alpha$-syn-GFP and synphilin, and either the empty vector pcDNA3.1 or CD. $24 \mathrm{~h}$ after transfection, cells were fixed and stained with a mouse monoclonal antibody against $\alpha$-syn (1:1000; BD transduction), and a secondary Alexa 488-conjugated goat anti-mouse antibody (1:500; Jackson ImmunoResearch). An observer blind to the transfection conditions scored neurons as positive or negative for $\alpha$-syn aggregates visible with a 20X objective under a fluorescent microscope. Three independent experiments were carried out with 4 replicates per experiment. Student t-test was used to compare transfection with empty vector versus transfection with CD.

\section{Cell culture and transfection}

The human neuroblastoma SHSY5Y cells were transfected in triplicate by vector alone, a-syn-GFP, pCMV-CD, or cotransfected by a-syn-GFP (or A53T, A30P, Y125A mutant a-syn) and pCMV-CD (or mutant CD) by Amaxa method as described by the vendor. Transfection efficiency was $80 \%$ as assessed by cells with or without GFP. $72 \mathrm{~h}$ after transfection, cells were harvested. For chloroquine (10 $\mathrm{mM}$ ) treatment, the chemicals were added $48 \mathrm{~h}$ after transfection, cells were harvested $42 \mathrm{~h}$ later. Live cells were counted by trypan blue exclusion. Relative cell survival was calculated as number of live cells after transfection by pCMV-CD and/or a-syn-GFP divided by live cells after transfection by vector alone. Elevated expression of a-synGFP or cathepsins was confirmed by western blot analyses using whole cell extracts.

\section{Western blot}

We homogenized wildtype and Ctsd-/- cortex ( $\mathrm{n} \geq 3$ each genotype) in 10 volumes of ice-cold lyses buffer $(50 \mathrm{mM}$ Tris- $\mathrm{HCl} \mathrm{pH} 7.4,175 \mathrm{mM} \mathrm{NaCl}, 5 \mathrm{mM}$ EDTA), sonicated for $10 \mathrm{sec}$, add TritonX-100 to $1 \%$ and incubated for 30 min on ice. We then centrifuged homogenates at $15,000 \mathrm{~g}$ for $15 \mathrm{~min}$ at $4^{\circ} \mathrm{C}$ to separate supernatants (fractions soluble in 1\% TritonX-100) and pellets (TritonX-100-insoluble fractions)[43]. Pellets were resuspended in lyses buffer containing 2\% SDS. Western blotting for each sample was done at least twice. The antibodies used were described in Immunohistochemistry.

\section{Quantitative PCR}

Total brain RNA was isolated from p25 mice using RNASTAT60 (Tel-Test, Friendswood, TX). Total RNA (2 $\mu \mathrm{g})$ was then reverse transcribed using Applied Biosystems GeneAmp Gold RNA PCR Reagent Kit (Foster City, CA). Real-time PCR reactions were setup in duplicate using TaqMan gene assays and amplified in an Applied Biosystems Step-One instrument. $\Delta \Delta \mathrm{CCT}$ curves were generated using 18S TaqMan gene assays as internal standards. Quantitative PCR results are shown as standard deviation of from 3 different amplifications from RNA reverse transcribed from 3 different animals. Individual gene assay kits were purchased from Applied Biosystems for each of the RNAs analyzed. Paired t-tests were conducted on RQ (relative quantity) values for each group to determine significance.

\section{Proteasome activity assays}

We analyzed the proteasome activities using the TritonX100 -soluble fractions. The assay buffer consists of $50 \mathrm{mM}$ Tris (pH7.5), 2.5 mM EGTA, 20\% glycerol, $1 \mathrm{mM}$ DTT, $0.05 \% \mathrm{NP}-40,50 \mu \mathrm{M}$ substrate. Lactacystin was used at a final concentration of $10 \mu \mathrm{M}$ to block proteasome activities as negative controls. Fluorescence was read at $5 \mathrm{~min}$ intervals for $2 \mathrm{~h}$, at an excitation wavelength of $380 \mathrm{~nm}$ 
and an emission wavelength of $460 \mathrm{nM}$. Assays were done in triplicate, each using $n \geq 3$ mice per genotype.

\section{C. elegans experiments}

Nematodes were maintained following standard procedures[69]. Worms expressing $\alpha$-syn alone UA49 [baInl2; $P_{\text {unc-54 }}:: \alpha$-syn:::gfp, rol-6 (su1006)] or with tor-2 [UA50;

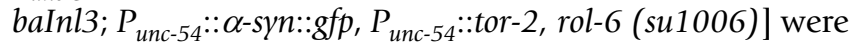
created, integrated into the genome to generate an isogenic line, and out-crossed four times. We used the worm line that overexpresses TOR-2 protein (a worm homolog of human torsinA) and a-syn fused to GFP in the body wall muscle cells because these cells are much larger than neurons for detecting a-syn aggregation. Moreover, C. elegans dopaminergic neurons have been shown to be refractory to RNAi. Using this isogenic line, we knocked down the worm Ctsd ortholog by RNAi, and scored for the return of a-syn aggregates over the course of development and aging.

RNAi was performed by bacterial feeding as described[70] with the following modification. A Ctsd-specific RNAi feeding clone targeting a distinct portion of the C. elegans open reading frame [R12H7.2 (asp-4); e-value $=1.8 \mathrm{e}-108]$ with highest homology to human Ctsd (Geneservice) was grown for $14 \mathrm{~h}$ in LB broth with $100 \mu \mathrm{g} / \mathrm{ml}$ ampicillin and seeded onto NGM agar plates containing $1 \mathrm{mM}$ isopropyl $\beta$-D-thiogalactoside. After $4 \mathrm{~h}$ incubation at $25^{\circ} \mathrm{C}$ to dry the plates, five gravid adults were then placed onto the corresponding RNAi plates and allowed to lay eggs for 9 $\mathrm{h}$; the resulting age-synchronized worms were analyzed at the indicated stage. RNAi knockdown was performed in duplicate sets of animals and enhancement $\alpha$-syn misfolding was scored as positive if at least $80 \%$ of worms displayed an increased quantity and size of $\alpha$-syn::GFP aggregates. For each trial, 20 worms were transferred onto a $2 \%$ agarose pad, immobilized with $2 \mathrm{mM}$ levamisole, and analyzed using Nikon Eclipse E800 epifluorescence microscope equipped with Endow GFP HYQ filter cube (Chroma Technology). Images were captured with a Cool Snap CCD camera (Photometrics) driven by MetaMorph software (Universal Imaging).

\section{Quantitative PCR from C. elegans}

The procedure for total RNA isolation, cDNA preparation, and semi-quantitative RT-PCR was described previously[71]. The following primers were used for the PCR: $c d k$-5 Primer 1: 5' ggg-gat-gat-gag-ggt-gtt-cca-agc 3'; Primer 2: 5' ggc-gac-cgg-cat-ttg-aga-tct-ctg-c 3'. tor-2 Primer 1: 5' caa-tta-tca-tgc-gtt-ata-caa-ag 3'; Primer 2: 5' cat-tcc-act-tcgata-agt-att-g 3'. $c d k-5$ Primer 1: 5' ggg-gat-gat-gag-ggt-gttcca-agc 3'; Primer 2: 5' ggc-gac-cgg-cat-ttg-aga-tct-ctg-c 3'. tor-2 Primer 1: 5' caa-tta-tca-tgc-gtt-ata-caa-ag 3'; Primer 2: $5^{\prime}$ cat-tcc-act-tcg-ata-agt-att-g $3^{\prime}$.
For the DA neurodegeneration analysis, strain UA54

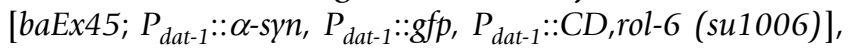
UA90 [baEx69; $P_{\text {dat }-1}:: \alpha-$ syn, $\quad P_{\text {dat }-1:: 8 f p,} P_{\text {dat }-1}:: C D$ D295R, rol-6 (su1006)], UA91 [baEx70; $P_{\text {dat }-1: \alpha-s y n,} P_{\text {dat }}$ ${ }_{1}:: g f p, P_{\text {dat } 1}:: C D$ F229I, rol-6 (su1006)], UA53 [baEx44; $P_{\text {dat- }}$ $1: \because \alpha$-syn, $P_{\text {dat }-1}:: g f p, P_{\text {dat }-1}:: C B$, rol-6 (su1006)], and UA55 [baEx46; $P_{\text {dat }-1}: \because \alpha-$ syn $, P_{\text {dat }-1}:: 8 f p, P_{\text {dat }-1}:: C L$, rol-6 (su1006)] were generated by injecting $50 \mu \mathrm{g} / \mathrm{ml}$ of expression plasmid containing the human cathepsin cDNA and $50 \mu \mathrm{g} / \mathrm{ml}$ of rol-6 into an integrated line of UA44 [baInl1; $P_{\text {dat }-1}:: \alpha$ syn, $\left.P_{\text {dat }-1}: g f p[72]\right]$. Three stable lines were randomly selected for neurodegeneration analysis. The 6 anterior DA neurons (4 CEP and 2 ADE neurons) of 30 animals/ trial were examined for neurodegeneration when the animals were 7 days old. 90 animals from each of three CD (or CD D295R, CD F229I, CB, and CL) transgenic lines were analyzed ( 3 lines $\times 3$ trials of 30 animals $/$ trial $=270$ total animals scored). Worms displaying at least one degenerative change (dendrite, axon, or cell body loss) were scored as exhibiting degenerating neurons as previously reported [44;72].

\section{Abbreviations}

$\alpha$-syn: alpha-synuclein; PD: Parkinson's disease; CD: Cathepsin D; GFP: green fluorescent protein; RNAi: RNA interference; UPS: ubiquitin-proteasome system.

\section{Competing interests}

KAC and GAC are scientific advisors to QRxPharma, Ltd. from whom they receive monetary compensation and a sponsored research agreement. The other authors have declared that no conflict of interest exists.

\section{Authors' contributions}

LQ performed the majority of the experiments of immunohistochemistry, western blot analyses, proteasome activity assays, and cell culture studies. SH, KAC and GAC contributed to all the findings in the worm. TAY contributed the $\alpha$-syn aggregation assay in $\mathrm{H} 4$ cells. SW contributed the real-time PCR. ZLX, RP, LDS, DC, QL, SC and LS assisted with various experiments. YU provided the LC3 antibody. TI provided the anti-phospho- $\alpha$-syn antibody. YZ constructed mammalian expression plasmids for GFP$\alpha$-syn. LP and YML constructed the mammalian expression plasmid for $\mathrm{CD}$. KCW, JJS and KAR contributed the original CD mutant mice, brain sections and extracts for our initial findings, helped with setting up western and immunohistochemistry techniques, and provided discussions on autophagy and CD. KAR was essential for identification of the $\alpha$-syn aggregates after immunostaining and provided neuropathology expertise, discussions, and assistance in writing the manuscript. DGS provided discussions and expertise in PD, $\alpha$-syn metabolism, and confocal microscopy. JZ directed the project and wrote the manuscript. 


\section{Acknowledgements}

We thank Songsong Cao for generating the $\alpha$-syn::GFP transgenic worms, Dr. Pam McLean for plasmids used for $\alpha$-syn aggregation assay in $\mathrm{H} 4$ cells, Drs. M Brenner and Y-F Chen for critically reading the manuscript, Drs. J Wu and J Tucholski, and members of our laboratories for technical assistance and discussions. Ctsd mutant mice were generously provided by Dr. P Saftig (University of Kiel). We thank Genta Ito for handling the shipping of the phospho- $\alpha$-syn antibody. This work is funded by the American Parkinson's Disease Association and Michael J. Fox Foundation (GAC, KAC, DGS), Batten Disease Support and Research Association, VA career development award, and UAB Alzheimer Disease Research Center (JJS), NIH grants NS35 107 and NS4 962 (KAR), a UAB faculty development and startup fund, UAB Alzheimer Disease Research Center, the American Parkinson's Disease Association, and Michael J. Fox Foundation (JZ). This work is also supported by UAB Neuroscience Core Facilities (NS47466 and NS57098). This work was also supported by the American Heart Association (055534I3, YL), NIH/NINDS (ROINS505I 383, YL) and NIH/NIA (ROIAG033282, YL).

\section{References}

I. Morris HR: Genetics of Parkinson's disease. Ann Med 2005, 37:86-96.

2. Webb JL, Ravikumar B, Atkins J, Skepper JN, Rubinsztein DC: AlphaSynuclein is degraded by both autophagy and the proteasome. J Biol Chem 2003, 278:25009-250I3.

3. Cuervo AM, Stefanis L, Fredenburg R, Lansbury PT, Sulzer D: Impaired degradation of mutant alpha-synuclein by chaperone-mediated autophagy. Science 2004, 305: I 292-1295.

4. Martinez-Vicente M, Talloczy Z, Kaushik S, Massey AC, Mazzulli J, Mosharov EV, Hodara R, Fredenburg R, Wu DC, Follenzi A, et al:: Dopamine-modified alpha-synuclein blocks chaperonemediated autophagy. J Clin Invest 2008.

5. Cuervo AM, Dice JF: When lysosomes get old. Exp Gerontol 2000, 35:||9-|3|.

6. Marino G, Lopez-Otin C: Autophagy: molecular mechanisms, physiological functions and relevance in human pathology. Cell Mol Life Sci 2004, 6 I: | 439-1454.

7. Yamamoto A, Cremona ML, Rothman JE: Autophagy-mediated clearance of huntingtin aggregates triggered by the insulinsignaling pathway. J Cell Biol 2006, I 72:719-73I.

8. Berger Z, Ravikumar B, Menzies FM, Oroz LG, Underwood BR, Pangalos MN, Schmitt I, Wullner U, Evert BO, O'Kane CJ, et al.: Rapamycin alleviates toxicity of different aggregate-prone proteins. Hum Mol Genet 2006, I 5:433-442.

9. Dean RT: Lysosomes and protein degradation. Ciba Found Symp 1979:139-149.

10. Jones EW, Zubenko GS, Parker RR: PEP4 gene function is required for expression of several vacuolar hydrolases in Saccharomyces cerevisiae. Genetics 1982, 102:665-677.

II. Hossain S, Alim A, Takeda K, Kaji H, Shinoda T, Ueda K: Limited proteolysis of NACP/alpha-synuclein. J Alzheimers Dis 2001, 3:577-584

12. Whitaker JN, Terry LC, Whetsell WO Jr: Immunocytochemical localization of cathepsin D in rat neural tissue. Brain Res 1981, 2 16:109-124.

13. Erickson AH, Blobel G: Carboxyl-terminal proteolytic processing during biosynthesis of the lysosomal enzymes beta-glucuronidase and cathepsin D. Biochemistry 1983, 22:5201-5205.

14. Cataldo AM, Barnett JL, Pieroni C, Nixon RA: Increased neuronal endocytosis and protease delivery to early endosomes in sporadic Alzheimer's disease: neuropathologic evidence for a mechanism of increased beta-amyloidogenesis. J Neurosci 1997, I 7:6142-6151.

15. Siintola E, Partanen S, Stromme P, Haapanen A, Haltia M, Maehlen J, Lehesjoki AE, Tyynela J: Cathepsin D deficiency underlies congenital human neuronal ceroid-lipofuscinosis. Brain 2006, 129:|438-|445.

16. Steinfeld R, Reinhardt K, Schreiber K, Hillebrand M, Kraetzner R, Bruck W, Saftig P, Gartner J: Cathepsin D deficiency is associated with a human neurodegenerative disorder. Am J Hum Genet 2006, 78:988-998.
17. Lavrov AY, llyna ES, Zakharova EY, Boukina AM, Tishkanina SV: The first three Russian cases of classical, late-infantile, neuronal ceroid lipofuscinosis. Eur J Paediatr Neurol 2002, 6: I 6 I- I 64.

18. Nijssen PC, Brusse E, Leyten AC, Martin JJ, Teepen JL, Roos RA: Autosomal dominant adult neuronal ceroid lipofuscinosis: parkinsonism due to both striatal and nigral dysfunction. Mov Disord 2002, I 7:482-487.

19. Zimran A, Neudorfer O, Elstein D: The glucocerebrosidase gene and Parkinson's disease in Ashkenazi Jews. N Engl J Med 2005, 352:728-73I.

20. Wong K, Sidransky E, Verma A, Mixon T, Sandberg GD, Wakefield LK, Morrison A, Lwin A, Colegial C, Allman JM, et al.: Neuropathology provides clues to the pathophysiology of Gaucher disease. Mol Genet Metab 2004, 82:192-207.

21. Saito Y, Suzuki K, Hulette CM, Murayama S: Aberrant phosphorylation of alpha-synuclein in human Niemann-Pick type CI disease. J Neuropathol Exp Neurol 2004, 63:323-328.

22. Suzuki K, Iseki E, Togo T, Yamaguchi A, Katsuse O, Katsuyama K, Kanzaki S, Shiozaki K, Kawanishi C, Yamashita S, et al.: Neuronal and glial accumulation of alpha- and beta-synucleins in human lipidoses. Acta Neuropathol (Berl) 2007, I I 4:48 I-489.

23. Hara T, Nakamura K, Matsui M, Yamamoto A, Nakahara Y, SuzukiMigishima R, Yokoyama M, Mishima K, Saito I, Okano H, et al.: Suppression of basal autophagy in neural cells causes neurodegenerative disease in mice. Nature 2006, 44I:885-889.

24. Komatsu M, Waguri S, Chiba T, Murata S, Iwata JI, Tanida I, Ueno T, Koike M, Uchiyama Y, Kominami E, et al.: Loss of autophagy in the central nervous system causes neurodegeneration in mice. Nature 2006, 44 I :880-884.

25. Eskelinen EL, Illert AL, Tanaka Y, Schwarzmann G, Blanz J, von FK, Saftig P: Role of LAMP-2 in lysosome biogenesis and autophagy. Mol Biol Cell 2002, I 3:3355-3368.

26. Bove J, Zhou C, Jackson-Lewis V, Taylor J, Chu Y, Rideout HJ, Wu DC, Kordower JH, Petrucelli L, Przedborski S: Proteasome inhibition and Parkinson's disease modeling. Ann Neurol 2006, 60:260-264.

27. Saftig P, Hetman M, Schmahl W, Weber K, Heine L, Mossmann H, Koster A, Hess B, Evers M, von FK, et al:: Mice deficient for the lysosomal proteinase cathepsin $D$ exhibit progressive atrophy of the intestinal mucosa and profound destruction of lymphoid cells. EMBO J 1995, I 4:3599-3608.

28. Koike M, Nakanishi H, Saftig P, Ezaki J, Isahara K, Ohsawa Y, SchulzSchaeffer W, Watanabe T, Waguri S, Kametaka S, et al.: Cathepsin $D$ deficiency induces lysosomal storage with ceroid lipofuscin in mouse CNS neurons. I Neurosci 2000, 20:6898-6906.

29. Koike M, Shibata M, Ohsawa Y, Nakanishi H, Koga T, Kametaka S, Waguri S, Momoi T, Kominami E, Peters C, et al.: Involvement of two different cell death pathways in retinal atrophy of cathepsin D-deficient mice. Mol Cell Neurosci 2003, 22: I46-I6I.

30. Koike M, Shibata M, Waguri S, Yoshimura K, Tanida I, Kominami E, Gotow T, Peters C, von FK, Mizushima N, et al.: Participation of autophagy in storage of lysosomes in neurons from mouse models of neuronal ceroid-lipofuscinoses (Batten disease). Am J Pathol 2005, 167:1713-1728.

31. Shacka JJ, Klocke BJ, Young C, Shibata M, Olney JW, Uchiyama Y, Saftig $P$, Roth KA: Cathepsin $D$ deficiency induces persistent neurodegeneration in the absence of Bax-dependent apoptosis. J Neurosci 2007, 27:208I-2090.

32. Suzuki K, Ohsumi Y: Molecular machinery of autophagosome formation in yeast, Saccharomyces cerevisiae. FEBS Lett 2007, 581:2|56-2|6|

33. Hasegawa M, Fujiwara $H$, Nonaka T, Wakabayashi K, Takahashi $H$, Lee VM, Trojanowski JQ, Mann D, Iwatsubo T: Phosphorylated alpha-synuclein is ubiquitinated in alpha-synucleinopathy lesions. J Biol Chem 2002, 277:4907 I-49076.

34. Anderson JP, Walker DE, Goldstein JM, de LR, Banducci K, Caccavello RJ, Barbour R, Huang J, Kling K, Lee M, et al.: Phosphorylation of Ser- 129 is the dominant pathological modification of alphasynuclein in familial and sporadic Lewy body disease. J Biol Chem 2006, 28 I:29739-29752.

35. Sampathu DM, Giasson BI, Pawlyk AC, Trojanowski JQ, Lee VM: Ubiquitination of alpha-synuclein is not required for formation of pathological inclusions in alpha-synucleinopathies. Am J Pathol 2003, I63:91-100. 
36. Fujiwara H, Hasegawa M, Dohmae N, Kawashima A, Masliah E, Goldberg MS, Shen J, Takio K, Iwatsubo T: alpha-Synuclein is phosphorylated in synucleinopathy lesions. Nat Cell Biol 2002, 4: I60-I64.

37. Neumann M, Kahle PJ, Giasson BI, Ozmen L, Borroni E, Spooren W, Muller V, Odoy S, Fujiwara H, Hasegawa M, et al.: Misfolded proteinase K-resistant hyperphosphorylated alpha-synuclein in aged transgenic mice with locomotor deterioration and in human alpha-synucleinopathies. J Clin Invest 2002, I I 0: |429-1439.

38. Hirai Y, Fujita SC, Iwatsubo T, Hasegawa M: Phosphorylated alpha-synuclein in normal mouse brain. FEBS Lett 2004, 572:227-232.

39. Cantuti-Castelvetri I, Klucken J, Ingelsson M, Ramasamy K, McLean PJ, Frosch MP, Hyman BT, Standaert DG: Alpha-synuclein and chaperones in dementia with Lewy bodies. J Neuropathol Exp Neurol 2005, 64:1058-1066

40. Nakanishi H, Zhang J, Koike M, Nishioku T, Okamoto Y, Kominami E, von FK, Peters C, Yamamoto $K$, Saftig $P$, et al.: Involvement of nitric oxide released from microglia-macrophages in pathological changes of cathepsin D-deficient mice. J Neurosci 200I, $21: 7526-7533$

4I. McLean PJ, Kawamata H, Hyman BT: Alpha-synuclein-enhanced green fluorescent protein fusion proteins form proteasome sensitive inclusions in primary neurons. Neuroscience 2001, 104:901-912.

42. Masliah E, Rockenstein E, Veinbergs I, Mallory M, Hashimoto $M$, Takeda A, Sagara Y, Sisk A, Mucke L: Dopaminergic loss and inclusion body formation in alpha-synuclein mice: implications for neurodegenerative disorders. Science 2000 , 287: $1265-1269$.

43. Giasson BI, Duda JE, Quinn SM, Zhang B, Trojanowski JQ, Lee VM: Neuronal alpha-synucleinopathy with severe movement disorder in mice expressing A53T human alpha-synuclein. Neuron 2002, 34:521-533.

44. Cooper AA, Gitler AD, Cashikar A, Haynes CM, Hill KJ, Bhullar B, Liu K, Xu K, Strathearn KE, Liu F, et al.: Alpha-synuclein blocks ERGolgi traffic and Rabl rescues neuron loss in Parkinson's models. Science 2006, 3 13:324-328.

45. St Martin JL, Klucken J, Outeiro TF, Nguyen P, Keller-McGandy C, Cantuti-Castelvetri I, Grammatopoulos TN, Standaert DG, Hyman BT, McLean PJ: Dopaminergic neuron loss and up-regulation of chaperone protein mRNA induced by targeted over-expression of alpha-synuclein in mouse substantia nigra. J Neurochem 2007, I00: |449-| 457

46. McLean PJ, Kawamata H, Shariff S, Hewett J, Sharma N, Ueda K, Breakefield $\mathrm{XO}$, Hyman BT: TorsinA and heat shock proteins act as molecular chaperones: suppression of alpha-synuclein aggregation. J Neurochem 2002, 83:846-854.

47. Tyynela J, Sohar I, Sleat DE, Gin RM, Donnelly RJ, Baumann M, Haltia $M$, Lobel P: $\mathbf{A}$ mutation in the ovine cathepsin $\mathbf{D}$ gene causes a congenital lysosomal storage disease with profound neurodegeneration. EMBO J 2000, 19:2786-2792.

48. Rideout HJ, Lang-Rollin I, Stefanis L: Involvement of macroautophagy in the dissolution of neuronal inclusions. Int J Biochem Cell Biol 2004, 36:255I-2562.

49. Pandey UB, Nie Z, Batlevi Y, McCray BA, Ritson GP, Nedelsky NB, Schwartz SL, DiProspero NA, Knight MA, Schuldiner O, et al.: HDAC6 rescues neurodegeneration and provides an essential link between autophagy and the UPS. Nature 2007, 447:859-863.

50. Stefanis L, Larsen KE, Rideout HJ, Sulzer D, Greene LA: Expression of A53T mutant but not wild-type alpha-synuclein in PCI 2 cells induces alterations of the ubiquitin-dependent degradation system, loss of dopamine release, autophagic cell death. J Neurosci 200I, 21:9549-9560.

5I. Bifsha P, Landry K, Ashmarina L, Durand S, Seyrantepe V, Trudel S, Quiniou C, Chemtob S, Xu Y, Gravel RA, et al:: Altered gene expression in cells from patients with lysosomal storage disorders suggests impairment of the ubiquitin pathway. Cell Death Differ 2007, I 4:5 I I-523.

52. Colell A, Ricci JE, Tait S, Milasta S, Maurer U, Bouchier-Hayes L, Fitzgerald P, Guio-Carrion A, Waterhouse NJ, Li CW, et al.: GAPDH and autophagy preserve survival after apoptotic cytochrome c release in the absence of caspase activation. Cell 2007, 1 29:983-997.
53. Tsuchiya K, Tajima H, Kuwae T, Takeshima T, Nakano T, Tanaka M, Sunaga K, Fukuhara Y, Nakashima K, Ohama E, et al.: Pro-apoptotic protein glyceraldehyde-3-phosphate dehydrogenase promotes the formation of Lewy body-like inclusions. Eur J Neurosci 2005, 21 :317-326.

54. Olah J, Tokesi N, Vincze O, Horvath I, Lehotzky A, Erdei A, Szajli E, Medzihradszky KF, Orosz F, Kovacs GG, et al:: Interaction of TPPP/p25 protein with glyceraldehyde-3-phosphate dehydrogenase and their co-localization in Lewy bodies. FEBS Lett 2006, 580:5807-58|4.

55. Furukawa K, Matsuzaki-Kobayashi M, Hasegawa T, Kikuchi A, Sugeno N, Itoyama Y, Wang Y, Yao PJ, Bushlin I, Takeda A: Plasma membrane ion permeability induced by mutant alpha-synuclein contributes to the degeneration of neural cells. J Neurochem 2006, 97: 107|-1077.

56. Smith WW, Jiang H, Pei Z, Tanaka Y, Morita H, Sawa A, Dawson VL, Dawson TM, Ross CA: Endoplasmic reticulum stress and mitochondrial cell death pathways mediate A53T mutant alphasynuclein-induced toxicity. Hum Mol Genet 2005, I 4:380 I-38I I.

57. Gosavi N, Lee HJ, Lee JS, Patel S, Lee S): Golgi fragmentation occurs in the cells with prefibrillar alpha-synuclein aggregates and precedes the formation of fibrillar inclusion. J Biol Chem 2002, 277:48984-48992.

58. Larsen KE, Schmitz Y, Troyer MD, Mosharov E, Dietrich P, Quazi AZ, Savalle M, Nemani V, Chaudhry FA, Edwards RH, et al.: Alpha-synuclein overexpression in PCI2 and chromaffin cells impairs catecholamine release by interfering with a late step in exocytosis. J Neurosci 2006, 26: I 1915-11922.

59. Volles MJ, Lansbury PT Jr: Relationships between the sequence of alpha-synuclein and its membrane affinity, fibrillization propensity, yeast toxicity. J Mol Biol 2007, 366:। 5 | $10-1522$.

60. Zhou Y, Gu G, Goodlett DR, Zhang T, Pan C, Montine TJ, Montine $\mathrm{KS}$, Aebersold RH, Zhang J: Analysis of alpha-synuclein-associated proteins by quantitative proteomics. J Biol Chem 2004, 279:39|55-39|64.

6I. Tanaka M, Kim YM, Lee G, Junn E, Iwatsubo T, Mouradian MM: Aggresomes formed by alpha-synuclein and synphilin-I are cytoprotective. J Biol Chem 2004, 279:4625-463I.

62. Hashimoto M, Hsu LJ, Rockenstein E, Takenouchi T, Mallory M, Masliah E: alpha-Synuclein protects against oxidative stress via inactivation of the c-Jun $\mathbf{N}$-terminal kinase stress-signaling pathway in neuronal cells. J Biol Chem 2002, 277: | |465-I|472.

63. Manning-Bog AB, McCormack AL, Purisai MG, Bolin LM, Di Monte DA: Alpha-synuclein overexpression protects against paraquat-induced neurodegeneration. I Neurosci 2003, 23:3095-3099.

64. Drolet RE, Behrouz B, Lookingland KJ, Goudreau JL: Mice lacking alpha-synuclein have an attenuated loss of striatal dopamine following prolonged chronic MPTP administration. Neurotoxicology 2004, 25:76I-769.

65. Robertson DC, Schmidt O, Ninkina N, Jones PA, Sharkey J, Buchman VL: Developmental loss and resistance to MPTP toxicity of dopaminergic neurones in substantia nigra pars compacta of gamma-synuclein, alpha-synuclein and double alpha/gammasynuclein null mutant mice. I Neurochem 2004, 89: I I 26-I I 36.

66. Dauer W, Kholodilov N, Vila M, Trillat AC, Goodchild R, Larsen KE, Staal R, Tieu K, Schmitz Y, Yuan CA, et al.: Resistance of alphasynuclein null mice to the parkinsonian neurotoxin MPTP. Proc Natl Acad Sci USA 2002, 99:| 4524- | 4529.

67. Fountaine TM, Wade-Martins R: RNA interference-mediated knockdown of alpha-synuclein protects human dopaminergic neuroblastoma cells from MPP(+) toxicity and reduces dopamine transport. I Neurosci Res 2007, 85:35I-363.

68. Hayashita-Kinoh H, Yamada M, Yokota T, Mizuno Y, Mochizuki H: Down-regulation of alpha-synuclein expression can rescue dopaminergic cells from cell death in the substantia nigra of Parkinson's disease rat model. Biochem Biophys Res Commun 2006, 34 I: 1088-1095.

69. Brenner S: The genetics of Caenorhabditis elegans. Genetics 1974, 77:71-94

70. Kamath RS, Ahringer J: Genome-wide RNAi screening in Caenorhabditis elegans. Methods 2003, 30:313-32I.

7I. Hamamichi S, Rivas RN, Knight AL, Cao S, Caldwell KA, Caldwell GA: Hypothesis-based RNAi screening identifies neuroprotective 
genes in a Parkinson's disease model. Proc Natl Acad Sci USA 2008, 105:728-733.

72. Cao S, Gelwix CC, Caldwell KA, Caldwell GA: Torsin-mediated protection from cellular stress in the dopaminergic neurons of Caenorhabditis elegans. J Neurosci 2005, 25:380I-38I2.

Publish with Bio Med Central and every scientist can read your work free of charge

"BioMed Central will be the most significant development for disseminating the results of biomedical research in our lifetime. " Sir Paul Nurse, Cancer Research UK

Your research papers will be:

- available free of charge to the entire biomedical community

- peer reviewed and published immediately upon acceptance

- cited in PubMed and archived on PubMed Central

- yours - you keep the copyright

Submit your manuscript here:

http://www.biomedcentral.com/info/publishing_adv.asp
BioMedcentral 